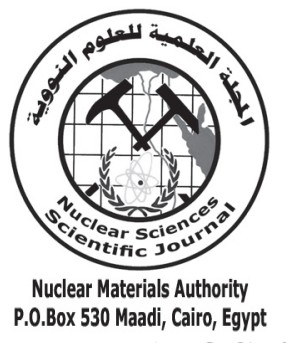

ISSN 2314-5609

Nuclear Sciences Scientific Journal

vol. 2, p 1 - 21

2013

\title{
MINERALOGICAL CHARACTERIZATION OF THE ALTERATION FACIES AT GABAL EL-MISSIKAT AREA, CENTRAL EASTERN DESERT, EGYPT
}

\author{
ANAS M. EL-SHERIF \\ Nuclear Materials Authority, P.O. Box 530, Maadi, Egypt
}

\begin{abstract}
The present study deals with the petrographical, mineralogical and geochemical characteristics of the alteration facies zones recognized around the shear zone at Gabal El-Missikat area, Central Eastern Desert, Egypt.

Petrographically, the fresh granitic samples are composed mainly of quartz, K-feldspars (microcline and microcline perthite), plagioclase, biotite. The secondary minerals are sericite, kaolinite, muscovite, chlorite and epidote as well as zircon, apatite, fluorite, titanite and iron oxides as accessory minerals.

Two alteration facies zones are recognized and namely as propylitic and advanced argillic. The propylitic facies zone is composed mainly of sericite with minor kaolinite, muscovite, quartz, relics of plagioclases, chlorite and rare epidote as well as zircon, hematite, goethite, magnetite, ilmenite, ilmenorutile, rutile, titanite, apatite, columbite and fluorite and secondary uranium minerals. the advanced argillic facies zone is composed mainly of kaolinite with minor sericite, quartz, muscovite, chlorite and rare epidote as well as zircon, hematite, goethite, magnetite, ilmenite, ilmenorutile, rutile, titanite, apatite and garnet of spessartine type as accessory minerals.

The identified minerals in the studied two alteration facies zones can be grouped into three mineral groups which are: the primary minerals (pyrite, magnetite, galena, columbite and gold), the secondary minerals (uranophane, kasolite and wulfenite) and the gangue minerals (anhydrite, barite, celestine, hematite, goethite and fluorite).

The identified mineral assemblage of the studied propylitic alteration facies zone may be attributed to strongly alkaline hydrothermal solutions at $\mathrm{pH}$ value of more than 7 with temperature varying between 350 and $450^{\circ} \mathrm{C}$, while the advanced argillic alteration facies zone is essentially associated with strongly acidic hydrothermal solutions at $\mathrm{pH}$ value less than 7 with temperature varying between 150 and $400^{\circ} \mathrm{C}$.
\end{abstract}

\section{INTRODUCTION}

Gabal El-Missikat area is located in the Central Eastern Desert of Egypt between Lat. $26^{\circ} 24^{\prime}$ and $26^{\circ} 30^{\prime} \mathrm{N}$ and Long. $33^{\circ} 15^{\prime}$ and $33^{\circ} 28^{\prime} \mathrm{E}$, (Fig. 1), closing to sign $\mathrm{km} 85$ on the Qena-Safaga paved road. Gabal El-Missikat occurs as a high mountain peak of younger granites (675m above sea level) intruding the low lying older granitoids.
Field relationships and observations confirm the presence of some different rock types in the study area such as metavolcanics, older granitoids, porphyry dyke swarms, younger granites and the Nubian Sandstone Formation.

The area was extensively studied by many workers since it was discovered by Ammar (1973). The detailed geology and radioactive mineralization of the area were described by 
El-Kassas (1974), Bakhit (1978), El-Shazly et al., (1981), Habib (1982), Abu-Deif (1985\&1992), Bakhit et al., (1985), El-Tahir (1985), Hussein et al., (1986), Bakhit and Mostafa (1987), Bakhit and El-Kassas (1989), Abdallah (1998) and Ibrahim (2002). The geochemistry was studied by Nagy (1977), Attawiya (1983) and Oraby (1999). The area was studied mineralogically by Ahmed (1991), Mohamed (1995), Ammar (2007) and Raslan (2009). The uranium exploration was studied by Rabie et al. (1996) and Abu-Deif and ElTahir (2008). Finally, the altered rocks in the area were studied and reported by Mohamed (1988), Abu-Deif et al., (1997), Ibrahim et al., (2004), Amer et al., (2005) and Abu-Deif et al., (2007).

Two alteration facies zones have been observed along the trend of the porphyry dykes and in between them. These zones include propylitic and advanced argillic facies. Abu-Deif et al.,(2007) concluded that the alteration processes resulted from hydrothermal solutions rather than meteoric water due to the presence of uranophane, samarskite, fluorite, zircon and apatite minerals in the alteration zones.
The present work deals mainly with the petrography, mineralogy and geochemistry of the two recognized facies zones of the altered granitic rocks and throws more light on the mode of formation of these zones.

\section{GEOLOGIC SETTING}

El-Missikat-Gidami (MG) younger granitic pluton (Fig. 1) represents a post-tectonic granite of Late Precambrian age characterized by high radioactivity. This granite is intruded into the older granitoids and metavolcanics, (Fig.2). The (MG) granite forms a pluton with circular outlines and can be separated into three concentric magmatic phases: MG1 peripheral zone followed by MG2 forming the main part of the pluton and by MG3 in the centre which occurs as several separate exposures intruded through MG2, (Fig.1). The grain size of these phases gradually increases from MG1 toward MG3, while the colour index decreases causing gradational contacts between the three phases, (Ibrahim et al., 2004).

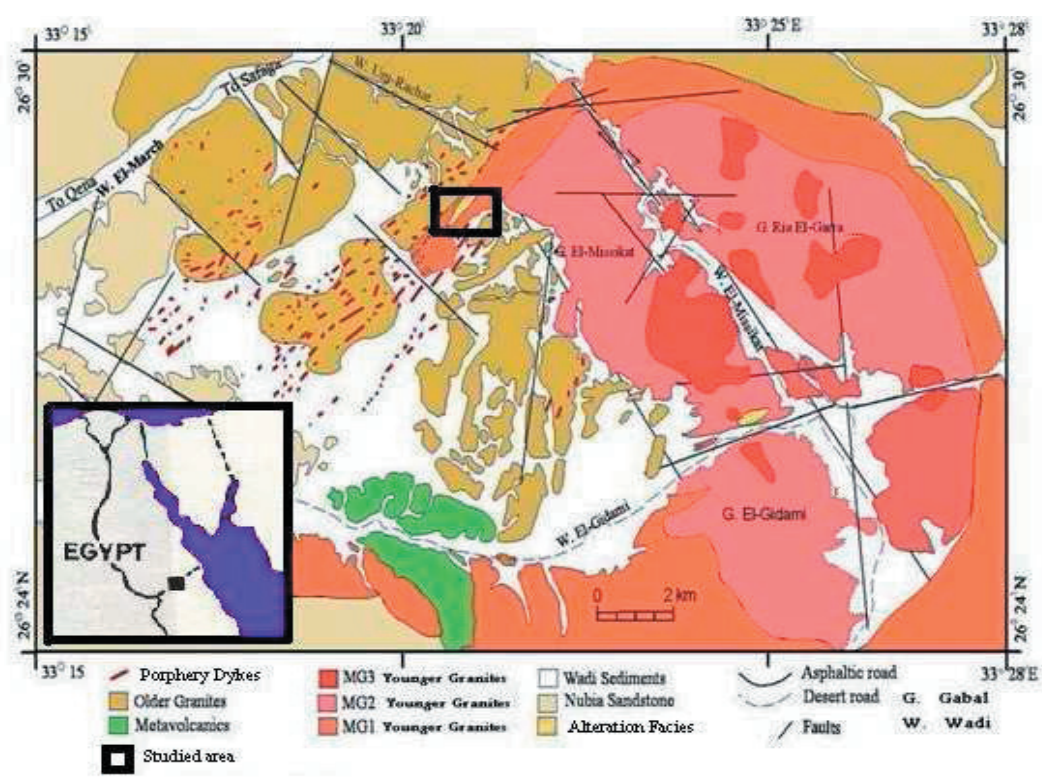

Fig. 1: Location and geological maps of El-Missikat area (After Amer et al., 2005) 


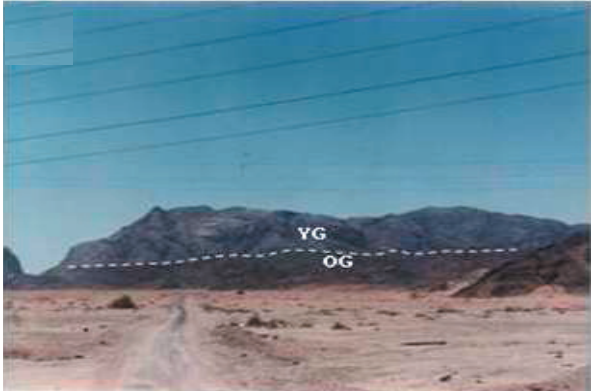

Fig.2 : High peak of younger granites (YG) intruded a low lying older granitoids (OG)

At the northwestern boundary of the MG granitic pluton, felsic dyke swarms trending NE-SW are present traversing the area. These dykes clearly cut the older granitoids, (Fig.3), but disappear at the younger granites. Between these dykes and along their NE extension, two alteration facies zones with or without U-mineralization are encountered associated with silica veins trending NE-SW to NNE-SSW. The NE-SW trend is a main tectonic trend in the area and seems to be reactivated many times, (Abu-Deif, 1985\&1992), where some granitic magma phases formed swarms of aplite and felsites porphyry dykes. These dykes extrude the older granitoids at the northwestern contact with younger granitic pluton.

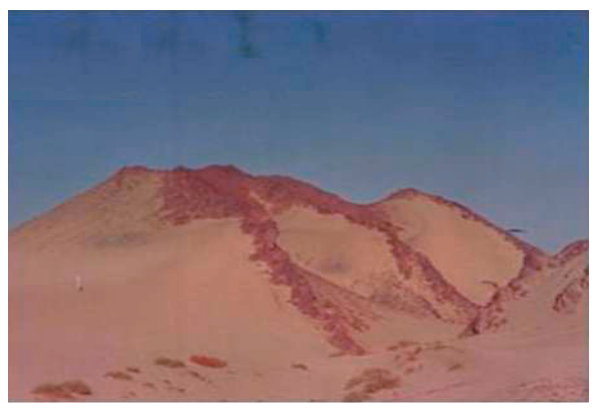

Fig. 3: Felsite dykes cut the older granitoids

Uranium mineralization in the study area is connected mainly to the jasperoid silica filling the fracture zone. It is discontinuous with high radioactivity, and is structurally controlled where it occurs along the fracture zone. It is preferably localized along the contact of the siliceous veins, along the secondary fractures, and at the intersections of fractures. Visible secondary U-minerals, probably uranophane, were encountered in several radioactive parts. They occur along micro-fracture surfaces, and coating cavities and vugs as thin films and fine clots, (Abu-Deif and El-Tahir, 2008).

The granitic rocks of El-Missikat area exhibit alteration, especially along the fractures. The studied area is characterized by two alteration facies zones being propylitic and advanced argillic facies according to the definition of Meyer and Hemely (1967). The altered granitic rocks that belong to the propylitic facies zone are characterized by green tone pronounced on both sides of the shear zone in the granitic rocks which can be observed with width ranging from few $\mathrm{cm}$ up to more than 30 meters. The iron oxides fill the cracks and coat most components of this zone, (Fig.4). Fluorite and quartz form veins are randomly distributed throughout the zone of the propylitic facies, (Figs.5\&6). The studied altered rocks belonging to the advanced argillic facies zone are characterized by their light colour (Fig.7) gradually following to the outside of the rocks of the propylitic facies zone and passes gradually into the unaltered granite, (Fig.8). The width of the advanced argillic facies zone ranges from few $\mathrm{cm}$ to more than $40 \mathrm{~m}$ on both sides. Some parts of the studied zone of the advanced argillic facies are stained with iron oxides and dissected by quartz veins and/or veinlets.

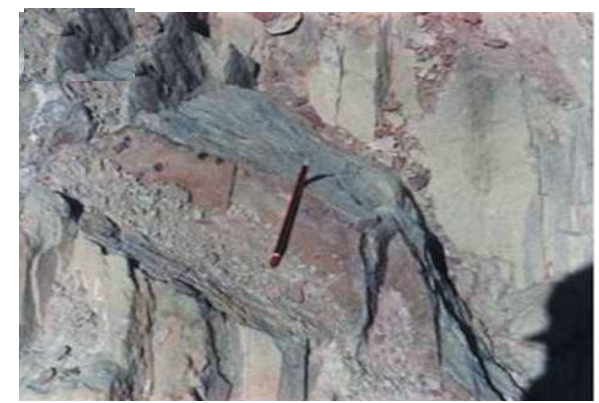

Fig.4 :Propylitic facies zone stained with iron oxides 


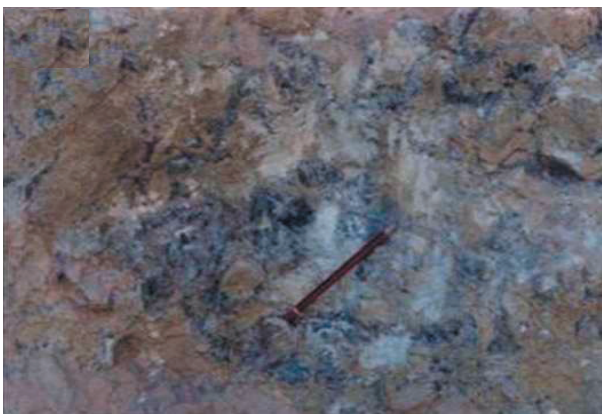

Fig. 5: Fluorite vein in the propylitic facies zone

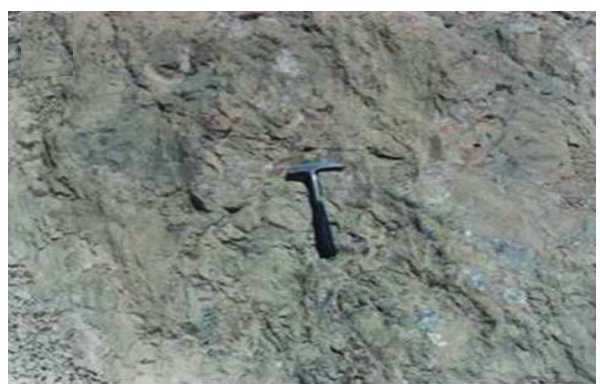

Fig.6: Quartz vein in the propylitic facies zone

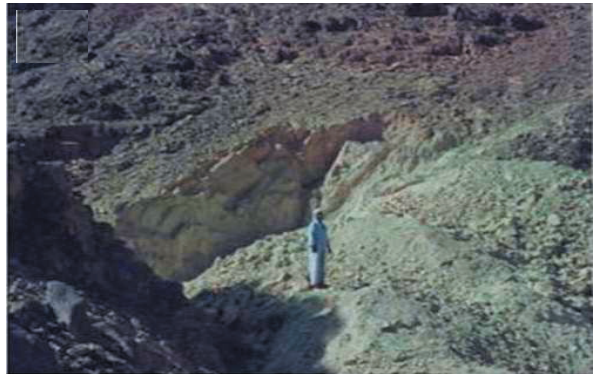

Fig.7:General view of the advanced argillic facies zone

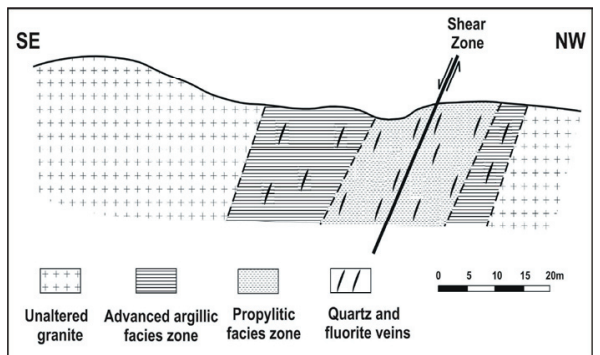

Fig.8: Estimated cross section of El-Missikat shear zone showing the alteration facies zones (Modified after AbuDeif et al., 2007)

\section{SAMPLING AND METHODOLOGY}

Six samples were collected from the alteration facies zones of El-Missikat granite pluton and subjected to petrographical, mineralogical, chemical and radiometric analyses. A Nickon polarizing microscope was used for the identification of the minerals and textures of the rocks under investigation.

For the mineralogical investigations, heavy liquids separation technique using bromoform of specific gravity $2.85 \mathrm{gm} / \mathrm{cm}^{3}$ was used to concentrate the heavy minerals. The interesting minerals were picked under binocular microscope to obtain pure mineral samples for $\mathrm{X}$-ray diffraction (XRD) as well as environmental scanning electron microscope (ESEM) investigation. The XRD technique was used to identify the unknown minerals using PHILIPS PW 3710/31 diffractometer. The ESEM model (PHILIPS XL 30) fitted with energy dispersive X-ray (EDAX) unit was used. The EDAX analysis is considered as semi-quantitative analysis since oxygen, carbon and hydrogen are not analyzed. The major oxides were analyzed using conventional wet chemical techniques of Shapiro and Brannock (1962). The $\mathrm{X}$-ray fluorescence technique, (XRF), was used to determine the trace element contents using PHILIPS X'Unique-II spectrometer. For the radiometric study, a multichannel analyzer Gamma ray spectrometer was used to determine the eU and eTh concentrations in the laboratory, (Matolin, 1990). All of the previously mentioned analyses were carried out in the laboratories of the Nuclear Materials Authority of Egypt, (NMA).

\section{PETROGRAPHICAL CHARACTERISTICS}

The studied area comprises the fresh younger granite as well as two main alteration mineral assemblages, a) propylitic assemblage characterized by the dominance of sericite and muscovite and b) advanced argillic assemblage characterized by the dominance of kaolinite. 


\section{The Fresh Granites}

Megascopically, these granites are medium-, to coarse-grained, hard and massive with pink colour. Under the microscope, the unaltered granites are composed mainly of quartz, plagioclases, K-feldspars (microcline and microcline perthite), and biotite. The secondary minerals are epidote, saussurite, sericite, muscovite, kaolinite and chlorite. The accessory minerals are zircon, apatite, fluorite, titanite and opaques. The XRD and ESEM analyses indicate that the opaque minerals are ilmenite, rutile and goethite.

Quartz commonly occurs as subhedral to anhedral crystals showing often wavy and undulose extinctions. It has inclusions of biotite and zircon. Plagioclases $\left(\mathrm{An}_{9-12}\right)$ are found as anhedral to subhedral tabular crystals exhibiting distinct lamellar twinning. They are sometimes intergrown with vermicular quartz forming myrmekitic texture. Some of them are slightly altered to saussurite whereas others are still fresh. Plagioclases often enclose zircon, apatite and opaque minerals. K-feldspars are represented by microcline and microcline perthite crystals with cross-hatched twinning, (Fig.9). They are sometimes altered to sericite and kaolinite as well as they enclose some plagioclases, quartz, biotite and opaque grains. Biotite forms pleochroic flakes ranging in colour from pale green yellow to light brown. It occurs often as fresh or slightly altered to chlorite and iron oxides along its cleavage planes, (Fig.10). Some biotite flakes include spots of opaque grains, titanite, zircon and apatite. Muscovite is usually rare. It occurs as irregular fine to medium size flakes of primary or secondary origin after sericite containing some elongated opaque spots particularly along its cleavage.

\section{Propylitic Facies Zone}

Megascopically, the propylitic facies zone samples are mostly compact showing pale green colour due to the alteration of K-feldspars to sericite as well as red colour due to staining with iron oxides. This zone is associated with quartz and fluorite veins and/or veinlets.

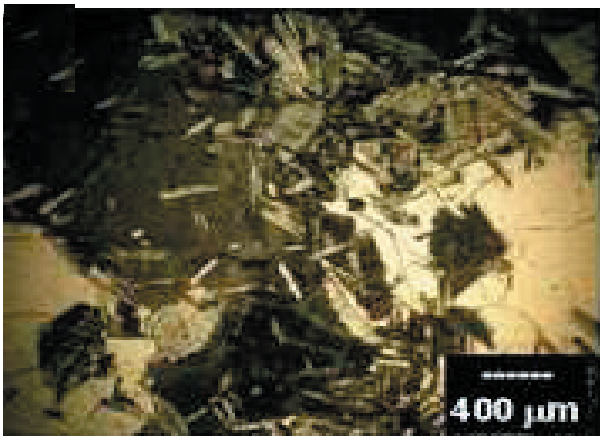

Fig.9 :Quartz associated with microcline perthite, microcline and plagioclase

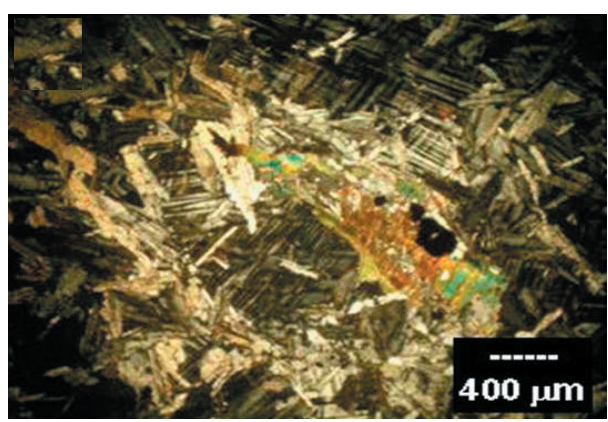

Fig.10: Biotite, muscovite, opaque iron oxides associated with sericite, microcline and microcline perthite

Microscopically, the propylitic facies zone consists mainly of K-feldspar altered to sericite and minor kaolinite as well as muscovite in addition to quartz, relics of plagioclases, chlorite and rare epidote. Sericite occurs as relics of microcline perthite, (Fig.11), sometimes mottled with iron oxide minerals (Fig.12). Kaolinite occurs with minor amount that can be identified by XRD technique (Fig.13). Muscovite occurs as flakes spotted with iron oxides and surrounded by sericite and associated with quartz, (Fig.14) or enclosed in plagioclase. Quartz occurs as cracked, elongated and fractured grains with undulose extinction, (Fig.14) sometimes surrounded by sericite and muscovite. Secondary quartz is mostly observed. Plagioclases $\left(\mathrm{An}_{10-15}\right)$ are partially or completely altered to saussurite and epidote and sometimes kaolinite and occur associated with microcline perthite, (Fig.15). Albitization is rarely observed. Chlorite occurs as greenish 
patches formed after biotite. Epidote is stained with iron oxides and associated with chlorite, (Fig.16). The accessory minerals in the propylitic facies zone are zircon, hematite, goethite, magnetite, ilmenite, ilmenorutile, rutile, titanite, apatite, columbite and fluorite were identified by XRD and ESEM.

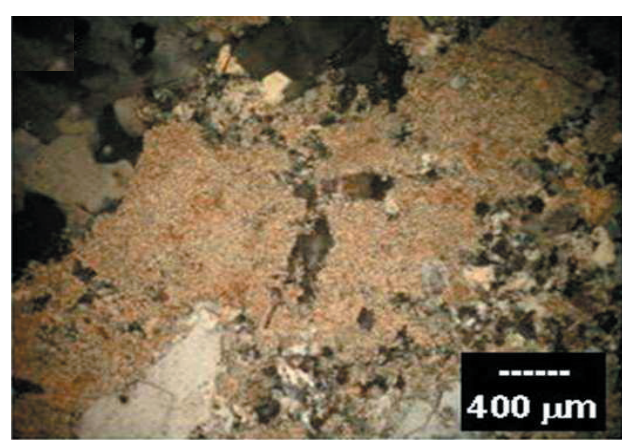

Fig.11:Sericite associated with relics of perthite

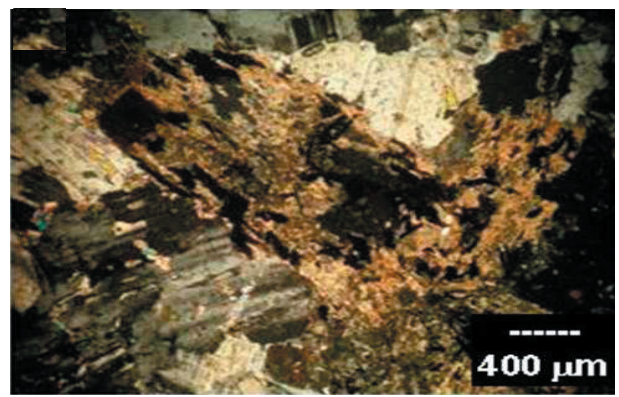

Fig.12: Saussuritized plagioclase mottled by opaque iron oxides

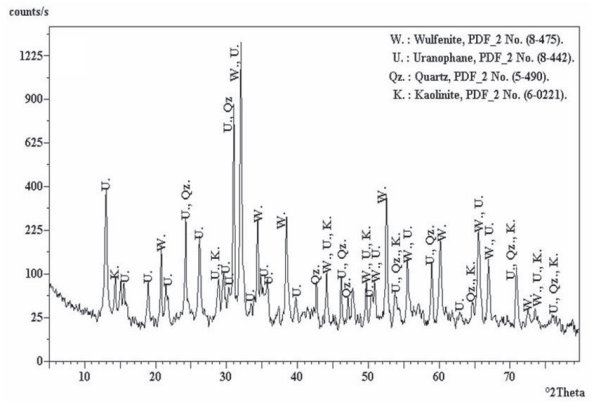

Fig.13: X-ray diffractogram ofWulfenite associated with kaolinite, uranophane and quartz

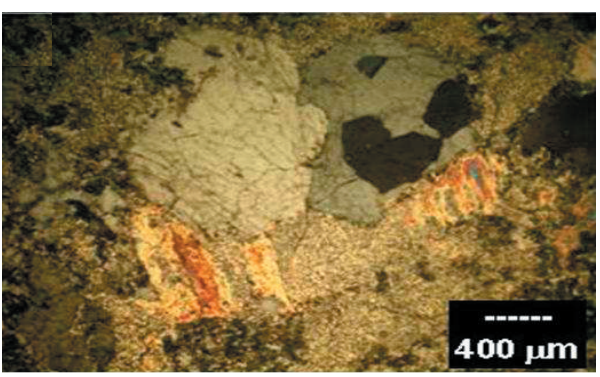

Fig.14: Muscovite mottled by opaque iron oxides and associated with quartz and sericite

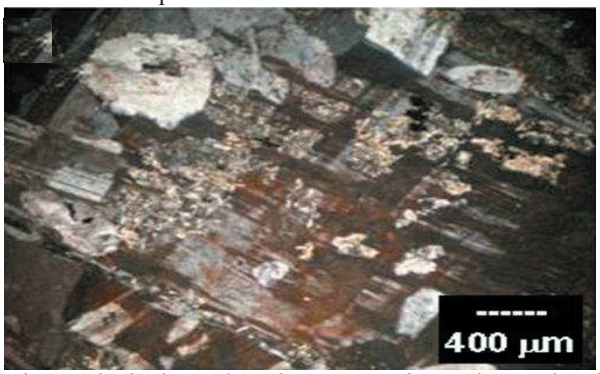

Fig.15:Plagioclase altered to saussurite and associated with relics of microcline perthite

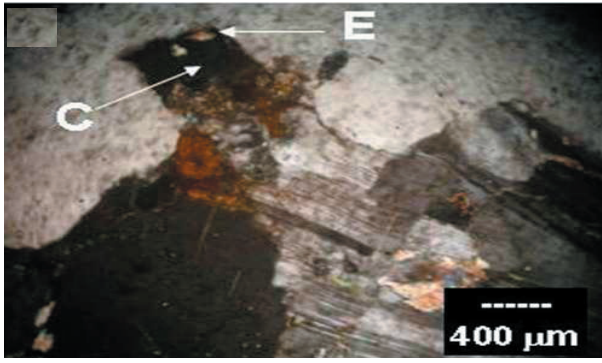

Fig.16: Epidote (E) stained with iron oxides and associated with chlorite (c)

\section{Advanced Argillic Facies Zone}

In hand specimens, the advanced argillic facies zone samples are fine-grained, compact, light in colour and more brittle than the wall rock due to the complete alteration of K-feldspars to kaolinite.

Microscopically, this zone is composed mainly of K-feldspars completely altered to kaolinite with some sericite, quartz, muscovite, chlorite and rare epidote. Kaolinite occurs as threads and sometimes stained with iron oxides (Fig.17) and can be identified with XRD technique (Fig.18). Primary quartz 
occurs as fractured anhedral grains with undulose wavy extinction, (Fig.19). Interstitial secondary clear quartz is recorded as anhedral small grains between other constituents. Muscovite after sericite is present mottled with iron oxides, (Fig.20). Chlorite occurs as small green pleochroic flakes after biotite. Epidote is rarely observed. Zircon, hematite, goethite, magnetite, ilmenite, ilmenorutile, rutile, titanite, apatite and garnet of spessartine type, occur as minute accessory grains and have been identified by XRD and ESEM.

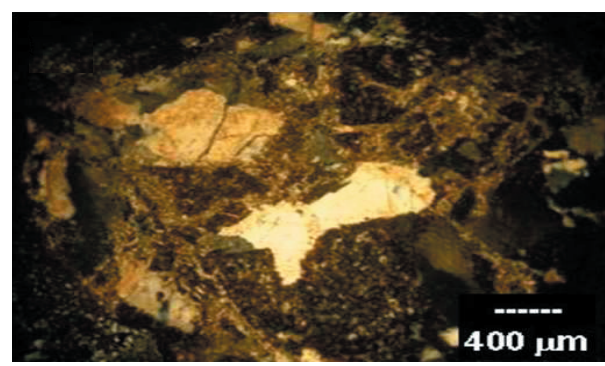

Fig.17:Completely alteration of K-feldspar to kaolinite which stained by opaque iron oxides

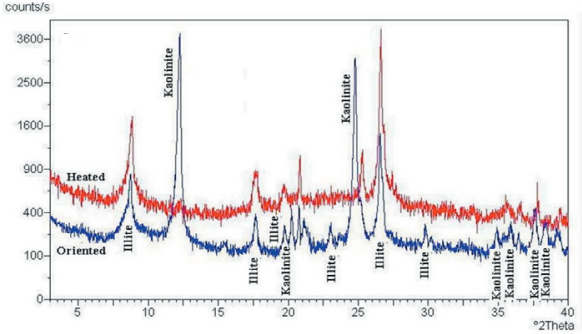

Fig.18: X-ray diffractogram of Oriented and heated clay minerals sample

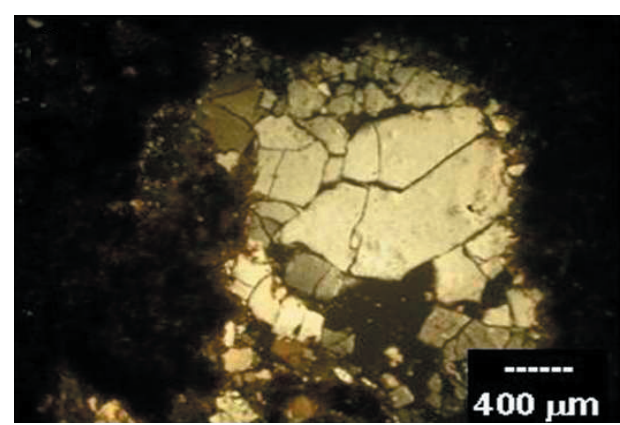

Fig.19:Cracked and fractured quartz associated with kaolinite

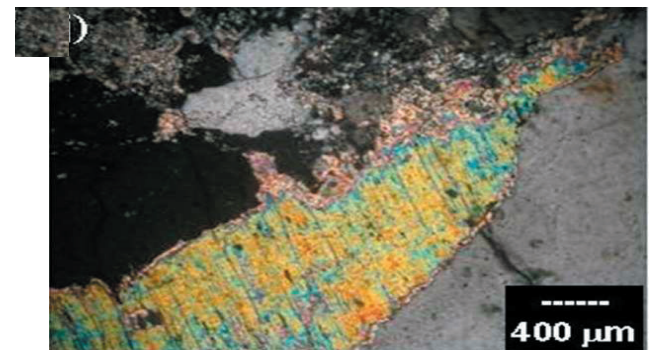

Fig.20:Muscovite mottled by opaque iron oxides and associated with sericite and cracked quartz

\section{MINERALOGY OF THE ALTERATION FACIES ZONES}

It is worth to mention that the concentrate fractions separated from the alteration facies zones of El-Missikat area are only minor. The study aims to identify the mineral constituents of the alteration facies zones in order to estimate their conditions and formation. Three main mineral groups have actually been identified as primary, secondary and gangue mineral groups.

\section{Primary Minerals}

The primary minerals group includes pyrite, magnetite, galena, columbite and gold Pyrite $\left(\mathrm{FeS}_{2}\right)$ occurs as the most abundant and widespread sulphide mineral. Pyrite is easily altered to goethite and/or hematite. Pyrite has been identified by XRD analysis (Fig.21) in the propylitic facies zone. Binocular microscope investigations show that pyrite occurs as anhedral, fine to medium grains with brownish-black colour and metallic luster (Fig.22).

Magnetite $\left(\mathrm{Fe}_{3} \mathrm{O}_{4}\right)$ is considered as one of the less stable mineral which easily altered to hematite, ulvospinel and finally ilmenite. The examined magnetite has been separated by hand magnet from both of the propylitic and advanced argillic facies zone samples. Microscopically, magnetite occurs as deep green subhedral crystals, (Fig.23). ESEM and semi-quantitative EDAX analyses, (Fig. 24 and Table 1), show that it has $2.19 \%$ of $\mathrm{SO}_{3}$. 


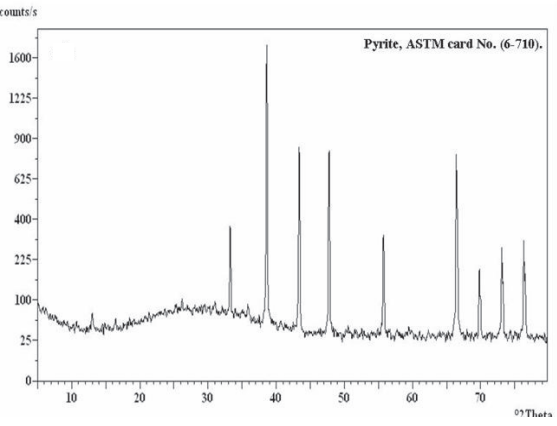

Fig.21: X-ray diffractogram of Pyrite

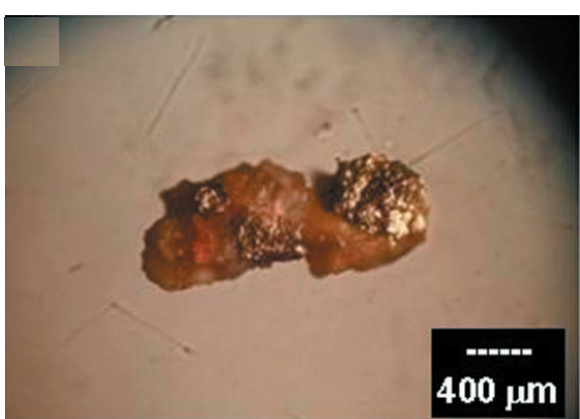

Fig.22: Dark brown pyrite grains stained with iron oxides

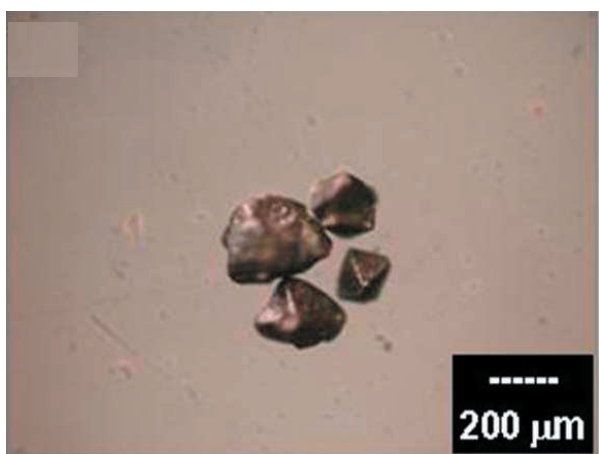

Fig.23:Greenish magnetite grains

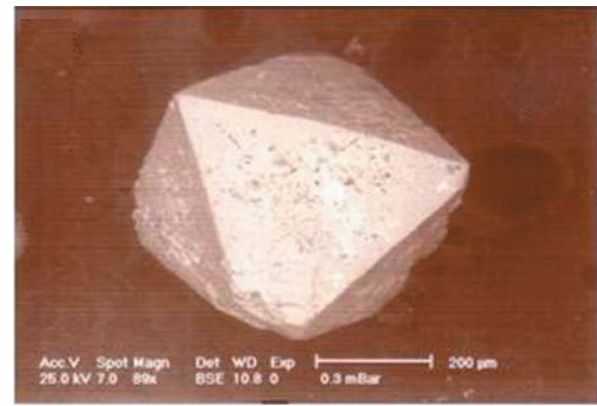

Fig.24: BSE image of Bi-pyramidal magnetite crystal in propylitic facies zone

Table 1: Semi-quantitative EDAX analysis data ( $\mathrm{wt} \%$ ) of primary and secondary mineral groups

\begin{tabular}{|c|c|c|c|c|c|c|c|c|c|}
\hline $\begin{array}{l}\text { Facies } \\
\text { zone }\end{array}$ & Propylitic & Propylitic & $\begin{array}{r}\text { Advanced } \\
\text { Argillic }\end{array}$ & $\begin{array}{r}\text { Advanced } \\
\text { Argillicic }\end{array}$ & Propylitic & Propylitic & Propylitic & Propylitic & Propylitic \\
\hline Mineral & Magnetite & Galena & Gold & $\begin{array}{r}\text { Inclusion } \\
\text { in gold }\end{array}$ & $\begin{array}{c}\text { Urano- } \\
\text { phane }\end{array}$ & $\begin{array}{r}\text { Radiated } \\
\text { Urano- } \\
\text { phane }\end{array}$ & Kasolite & $\begin{array}{r}\text { Kasolite } \\
\text { inclusion } \\
\text { in } \\
\text { magnetite }\end{array}$ & Wulfenite \\
\hline $\mathrm{F}_{2} \mathrm{O}$ & --- & --- & --- & 1.39 & --- & --- & -- & --- & --- \\
\hline $\mathrm{Na}_{2} \mathrm{O}$ & --- & --- & --- & 1.45 & --- & -- & --- & --- & --- \\
\hline MgO & 2.72 & -- & -- & 6.26 & --- & -- & -- & --- & -- \\
\hline $\mathrm{Al}_{2} \mathrm{O}_{3}$ & 7.62 & --- & -- & 11.35 & 0.55 & & 0.9 & 1.36 & --- \\
\hline $\mathrm{SiO}_{2}$ & 2.19 & 2.98 & --- & 23.33 & 8.07 & 1.59 & 6.49 & 7.36 & 4.59 \\
\hline $\mathrm{SO}_{3}$ & --- & 17.61 & --- & --- & --- & -- & -- & --- & --- \\
\hline $\mathrm{Au}_{2} \mathrm{O}$ & --- & -- & 100 & 25.97 & --- & -- & -- & --- & --- \\
\hline $\mathrm{ThO}_{2}$ & --- & --- & --- & 1.85 & --- & --- & --- & --- & --- \\
\hline AgO & --- & -- & -- & 4.41 & --- & -- & -- & -- & --- \\
\hline $\mathrm{K}_{2} \mathrm{O}$ & --- & --- & --- & 0.77 & --- & 1.1 & 3.61 & 2.91 & --- \\
\hline $\mathrm{CaO}$ & 0.88 & 1.16 & --- & 1.10 & 9.46 & 2.62 & 3.34 & 1.88 & --- \\
\hline $\mathrm{TiO}_{2}$ & --- & --- & --- & 4.43 & --- & -- & -- & --- & --- \\
\hline $\mathrm{Fe}_{2} \mathrm{O}_{3}$ & 86.59 & --- & --- & 17.69 & --- & 3.26 & 2.47 & 23.58 & --- \\
\hline $\mathrm{PbO}_{2}$ & --- & 78.25 & --- & -- & --- & 2.16 & 12.99 & 28.56 & 60.06 \\
\hline $\mathrm{Mo}_{2} \mathrm{O}_{3}$ & --- & --- & --- & --- & --- & -- & --- & --- & 35.35 \\
\hline $\mathrm{UO}_{2}$ & -- & --- & -- & -- & 81.92 & 89.27 & 70.27 & 34.35 & -- \\
\hline
\end{tabular}


Galena $(\mathrm{PbS})$ has been identified in the propylitic and advanced argillic facies zones. Under the microscope, galena has usually gray colour, metallic luster and cubic cleavage, (Fig.25). ESEM and semi-quantitative EDAX analyses show that it has $78.23 \%$ of $\mathrm{PbO}_{2}$ (Fig.26 and Table 1).

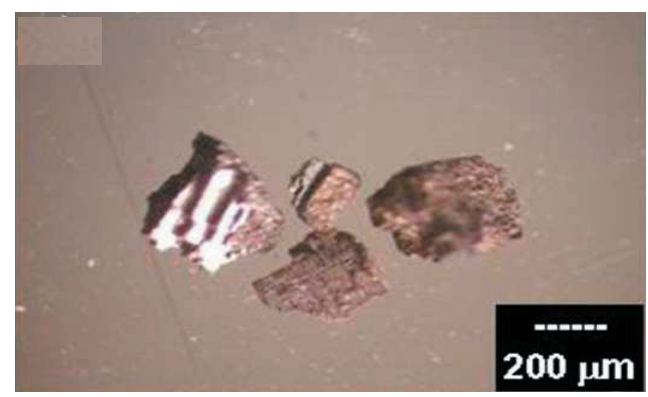

Fig.25:Lead gray galena grains

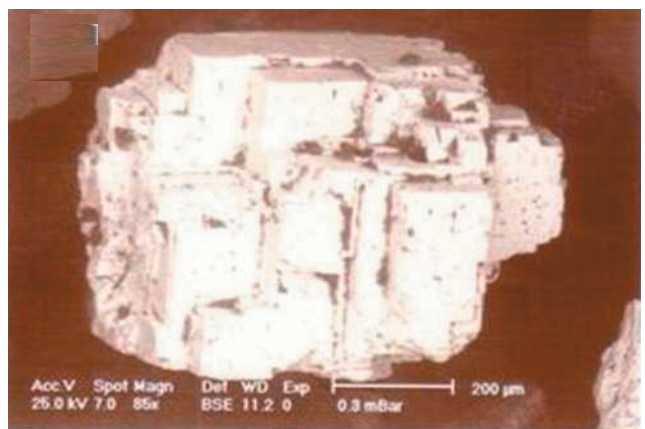

Fig.26: BSE image of Galena particle in propylitic facies zone

Columbite $\left(\mathrm{Fe}^{2+}, \mathrm{Mn}\right)(\mathrm{Nb}, \mathrm{Ta})_{2} \mathrm{O}_{6}$ belongs to columbite-tantalite series. It is called columbite when niobium predominates. XRD diffractogram of the obtained columbite is shown on Figure (27). The investigated columbite found in the propylitic facies zone is enclosed in quartz, (Fig.28). Columbite of the metasomatized granite is characterized by high Ti and U and low Ta contents. Heinrich (1962) suggested that U-bearing columbite is Ta-poor. He also stated that the U content increases with the decreasing temperature of crystallization.

Gold $(\mathrm{Au})$ is one of the most popular and well-known minerals for its value and spe- cial properties since the earliest time. Gold is mostly concentrated, in small quantities, in the entire studied alteration facies zones of ElMissikat area. Microscopically, gold occurs as bright golden yellow flakes with high metallic luster, (Fig.29). ESEM and semi-quantitative EDAX analyses, (Fig.30 and Table 1), show that studied gold was found in a pure state or has inclusions of $\mathrm{Ag}$ and $\mathrm{ThO}_{2}$, (Fig.31).

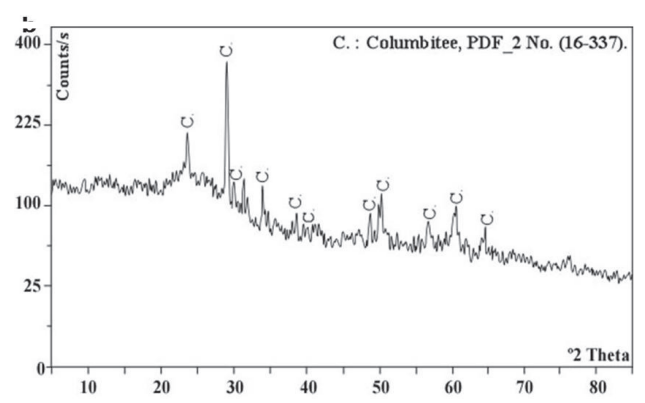

Fig.27: X-ray diffractogram of Columbite

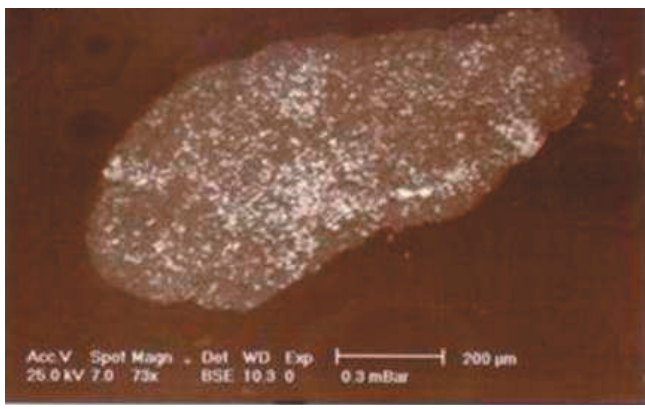

Fig.28: BSE image of Quartz particle enclosing columbite propylitic facies zone

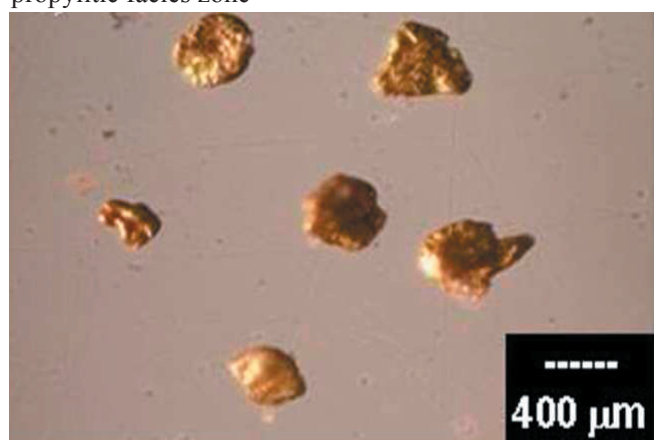

Fig.29: Native gold grains 


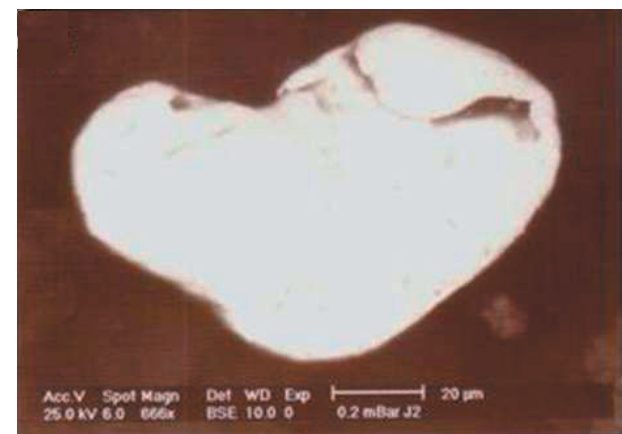

Fig.30:Pure gold particle in advanced argillic facies zone

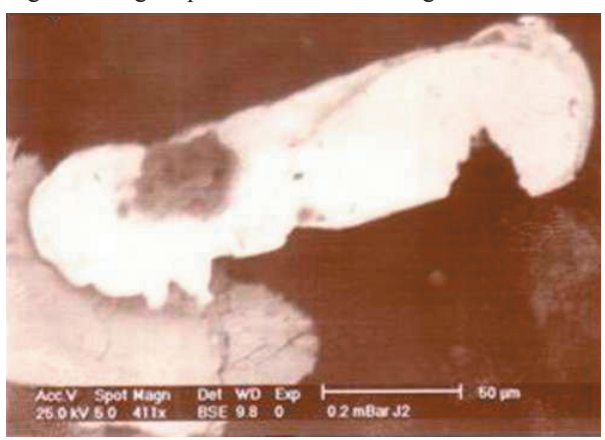

Fig.31:Gold particle with inclusion in propylitic facies zone

\section{Secondary Minerals Group}

The secondary minerals group includes uranophane, kasolite and wulfenite. Uranophane $\mathrm{Ca}\left(\mathrm{UO}_{2}\right)_{2}\left(\mathrm{SiO}_{3}\right)_{2}(\mathrm{OH})_{2} \cdot 5\left(\mathrm{H}_{2} \mathrm{O}\right)$ is actually the most predominant radioactive mineral in El-Missikat area particularly in the propylitic facies zone. Identification of uranophane has been confirmed by XRD analysis, (Fig.32). Under the binocular microscope, it occurs mainly in massive form with yellow colour and dull luster (Fig.33) and sometimes it exhibits radiated shape, (Fig.34). ESEM and semi-quantitative EDAX analyses, (Figs.35\&36 and Table 1) show that the separated uranophane from the propylitic facies zone has $\mathrm{UO}_{2}$ content reaching up to $89.27 \%$.

Kasolite $\mathrm{Pb}\left(\mathrm{UO}_{2}\right) \mathrm{SiO}_{3}(\mathrm{OH})_{2}$ is a less common secondary uranium mineral in the studied area. Kasolite is found as separate mineral or enclosed in magnetite in the propylitic facies zone, (Table 1).
Figure (37) shows the XRD pattern of the study kasolite associated with muscovite, albite and clinochlore. Microscopically, kasolite occurs as massive granular masses having resinous to greasy luster and lemon yellow colour, (Fig.38). ESEM and semiquantitative EDAX analyses, (Fig.39 and Table 1), show that the separated kasolite from the propylitic facies zone has $\mathrm{UO}_{2}$ content twice that of kasolite enclosed in the magnetite.

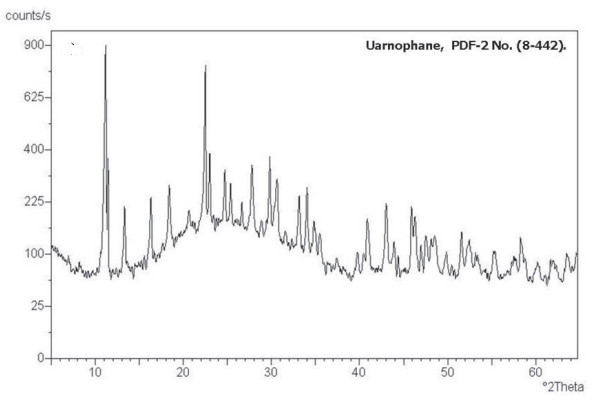

Fig.32: X-ray diffractogram of Uranophane

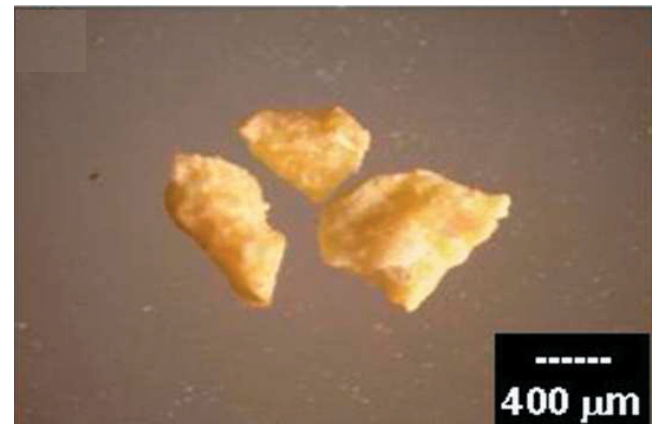

Fig.33:Yellow uranophane grains

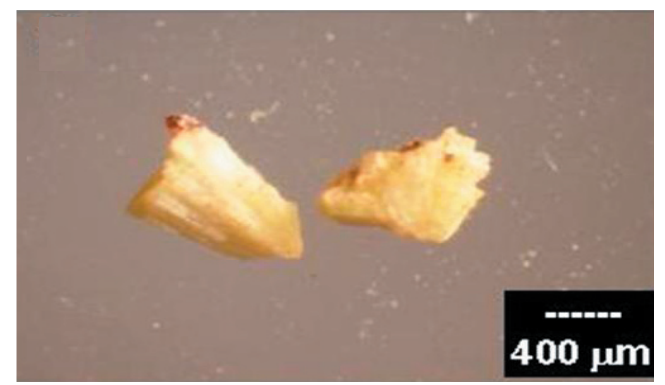

Fig.34: Radiated uranophane grains 


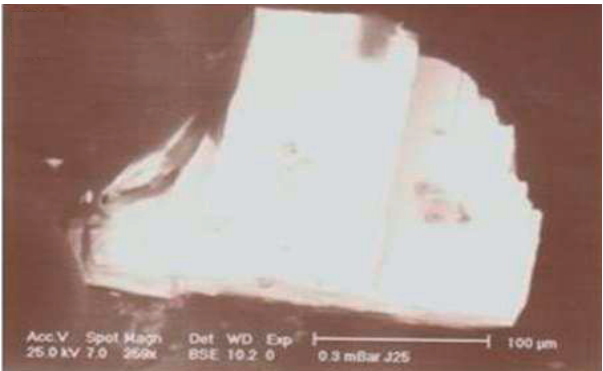

Fig.35:Uranophane particle in propylitic facies zone

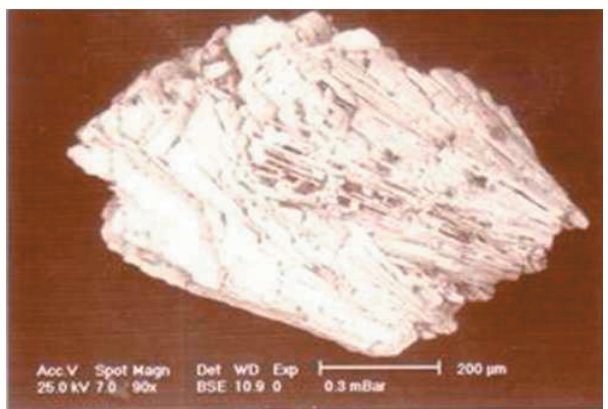

Fig.36:Radiated uranophane particle in propylitic facies zone

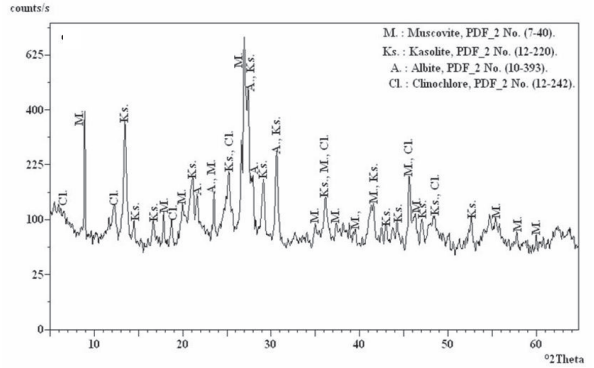

Fig.37: X-ray diffractogram of Kasolite associated with muscovite, albite and clinochlore

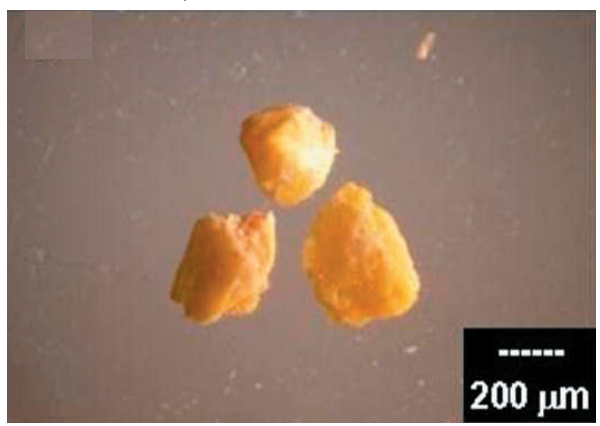

Fig.38: Lemon yellow kasolite

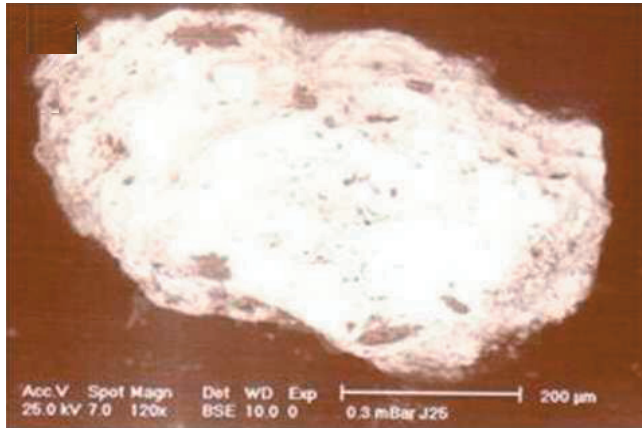

Fig.39:Kasolite particle in propylitic facies zone

Wulfenite $\mathrm{PbMoO}_{4}$ is considered as the result of the decomposition of lead minerals or derived from the chemical alteration, (Deer et al. 1966). Wulfenite is recorded for the first time in the alteration facies zones of El-Missikat area that can be identified easily by XRD, (Fig.13). It is only found in the propylitic facies zone as massive, translucent squares and tabular crystals of pale brown colour, (Fig.40). ESEM investigation and semi-quantitative EDAX analyses, (Fig.41 and Table 1), show that the investigated wulfenite mineral has $60.06 \%$ of $\mathrm{PbO}_{2}$ and $35.35 \%$ of $\mathrm{Mo}_{2} \mathrm{O}_{2}$.

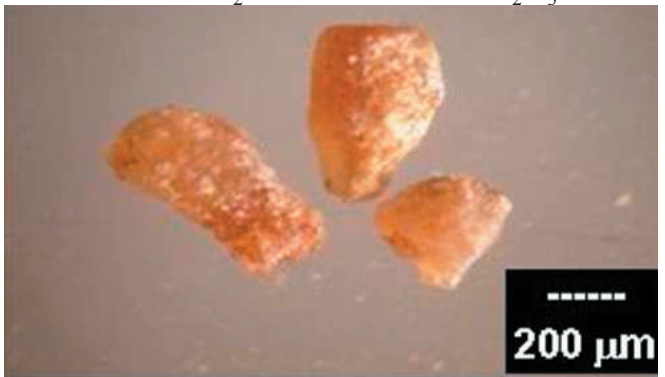

Fig.40: Pale brown wulfenite grains

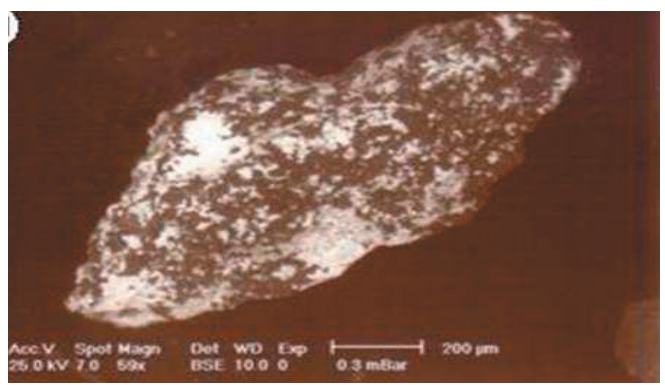

Fig.41:Wulfenite particle in propylitic facies zone 


\section{Gangue Minerals Group}

The gangue minerals group includes the sulphate minerals (anhydrite, barite and celestine), the iron oxide minerals (hematite and goethite) as well as fluorite.

Anhydrite $\left(\mathrm{CaSO}_{4}\right)$ is identified for the first time in El-Missikat area. It occurs microscopically as distinct fibers of light gray colour and fine-grained form, (Fig. 42). ESEM and semiquantitative EDAX analyses, (Figs. 43\&44 and Table 2), indicate that the study anhydrite grains are sometimes stained with iron oxides or have inclusions of galena in the propylitic facies zone. The XRD diffractogram (Fig.45) shows the presence of anhydrite associating hematite, quartz and muscovite.

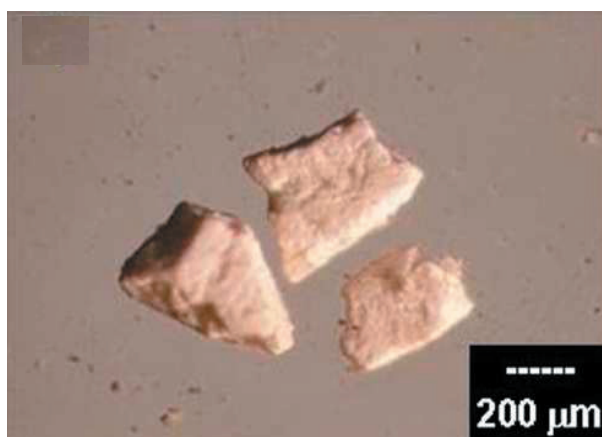

Fig.42:Gray anhydrite grains

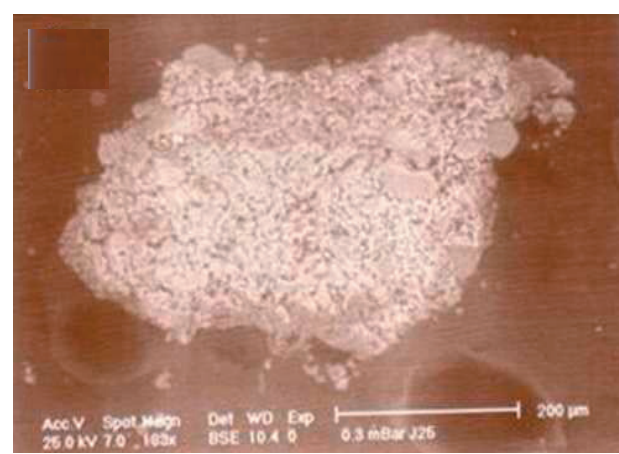

Fig.43:Anhydrite particle in propylitic facies zone

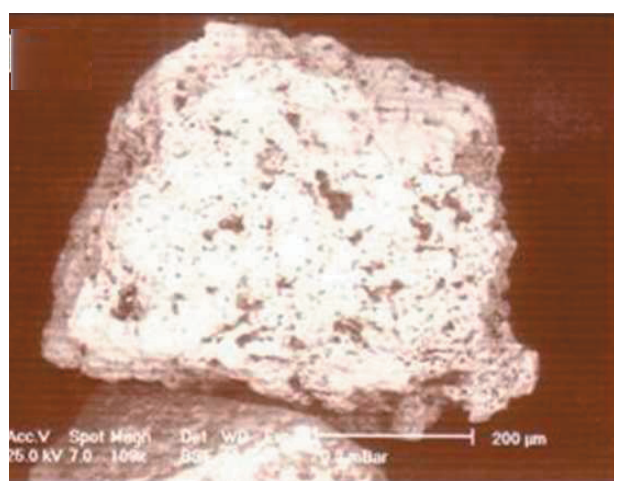

Fig.44:Anhydrite particle in advanced argillic facies zone

Table 2: Semi-quantitative EDAX analysis data (wt\%) of gangue minerals group

\begin{tabular}{|c|c|c|c|c|c|c|c|c|c|c|}
\hline $\begin{array}{l}\text { Facies } \\
\text { zone }\end{array}$ & Propylitic & Propylitic & Propylitic & $\begin{array}{c}\text { Advanced } \\
\text { Argillic }\end{array}$ & Propylitic & $\begin{array}{c}\text { Advanced } \\
\text { Argillic }\end{array}$ & Propylitic & Propylitic & Propylitic & Propylitic \\
\hline Mineral & Anhydrite & $\begin{array}{r}\text { Anhydrite } \\
\text { encloses } \\
\text { galena } \\
\end{array}$ & Barite & Barite & Celestine & Hematite & Goethite & $\begin{array}{l}\text { Violet } \\
\text { Fluorite }\end{array}$ & $\begin{array}{r}\text { Fluorite } \\
\text { encloses } \\
\text { barite }\end{array}$ & $\begin{array}{r}\text { Black } \\
\text { Fluorite }\end{array}$ \\
\hline $\mathrm{MgO}$ & $\overline{---}$ & 1.71 & -.- & --. & 1.45 & 4.22 & -.- & -- & --- & -.. \\
\hline $\mathrm{Al}_{2} \mathrm{O}_{3}$ & 0.86 & 2.06 & 0.65 & 19.02 & 2.45 & 10.29 & 2.67 & --- & --- & --. \\
\hline $\mathrm{SiO}_{2}$ & 0.18 & 5.55 & 1.46 & 21.97 & 2.42 & 22.37 & 8.02 & 0.30 & 0.98 & 1.22 \\
\hline $\mathrm{SO}_{3}$ & 58.85 & 15.19 & 32.64 & 21.12 & 48.40 & --- & --- & --- & 4.23 & -- \\
\hline $\mathrm{K}_{2} \mathrm{O}$ & --- & --- & -- & 3.17 & 0.83 & --- & -- & --- & --- & -- \\
\hline $\mathrm{CaO}$ & 39.78 & 24.76 & 1.19 & --- & 1.45 & 0.78 & --. & 62.75 & 54.98 & 52.45 \\
\hline $\mathrm{BaO}$ & --- & --. & 51.91 & 34.48 & --- & --- & --- & -- & 9.13 & -- \\
\hline SrO & --- & --- & -- & --- & 44.44 & --- & --- & --- & --- & -- \\
\hline $\mathrm{Fe}_{2} \mathrm{O}_{3}$ & 0.34 & 1.34 & 2.37 & --- & --- & 52.78 & 89.31 & --- & --- & 0.72 \\
\hline $\mathrm{ZnO}$ & -- & -- & 9.77 & -- & -- & 4.46 & -- & -- & --- & -- \\
\hline $\mathrm{PbO}_{2}$ & -- & 49.40 & -- & --- & -- & 5.10 & --. & -- & --- & - \\
\hline $\mathrm{F}_{2} \mathrm{O}$ & -- & -- & -- & -- & -- & -- & -- & 36.95 & 26.50 & 45.24 \\
\hline $\mathrm{ClO}_{2}$ & --- & -- & -- & --- & -- & --- & --. & --- & 0.74 & -- \\
\hline $\mathrm{YB}_{2} \mathrm{O}_{3}$ & --- & -- & -- & -- & --- & -- & --- & -- & 2.17 & -- \\
\hline $\mathrm{Y}_{2} \mathrm{O}_{3}$ & - & -- & -- & -- & -- & -- & -- & -- & 1.27 & 0.37 \\
\hline
\end{tabular}




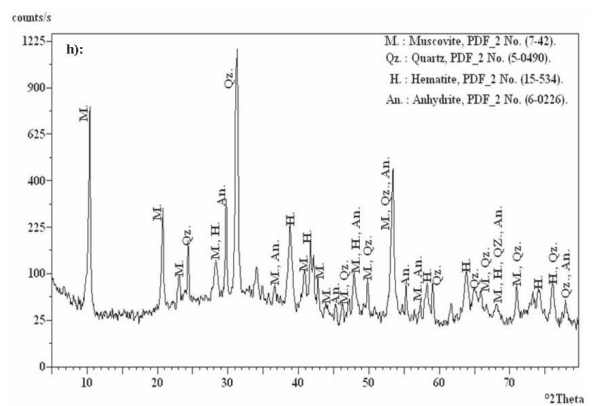

Fig.45: X-ray diffractogram of Anhydrite associated with hematite, quartz and muscovite

Barite $\left(\mathrm{BaSO}_{4}\right)$ can be identified microscopically as platy fine yellowish grains, (Fig. 46). The XRD diffractogram (Fig. 47) shows the presence of barite mineral in the studied two alteration facies zones. ESEM and semiquantitative EDAX analyses, (Figs. 48\&49 and Table 2) indicate that the studied barite grains are stained with iron oxides in the propylitic facies zone and associated with clays in the advanced argillic facies zone.

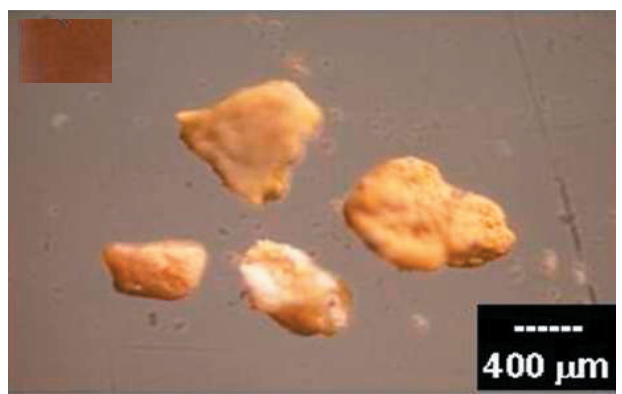

Fig.46: Yellowish barite grains

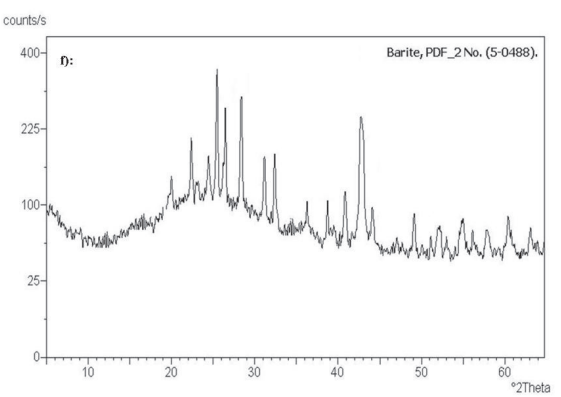

Fig.47: X-ray diffractogram of Barite

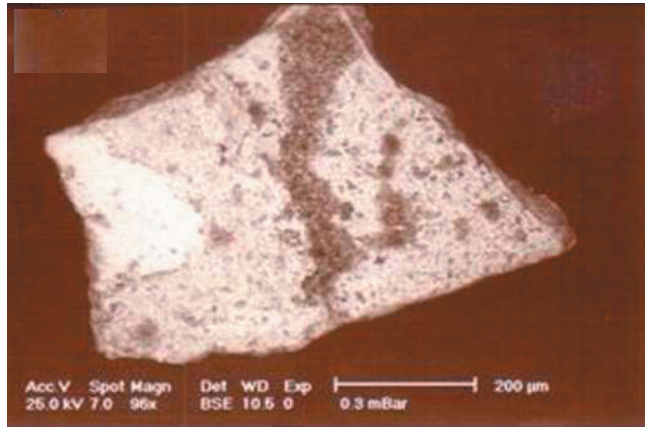

Fig.48:Barite particle in propylitic facies zone

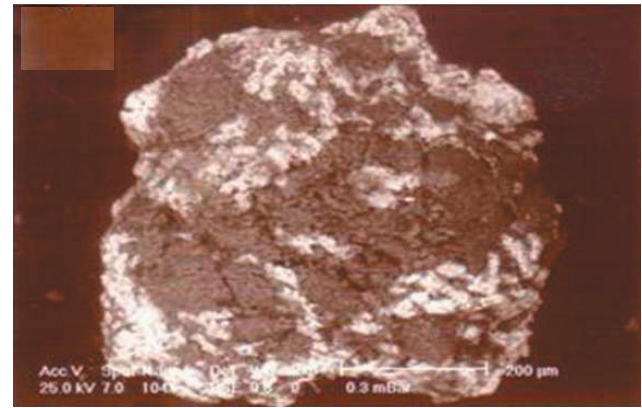

Fig.49:Barite particle stained with clay in advanced argillic facies zone

Celestine $\left(\mathrm{SrSO}_{4}\right)$ is also detected for the first time in the alteration facies zones of ElMissikat area with structure habit similar to anhydrite and barite with Sr taking the place of $\mathrm{Ca}$ or $\mathrm{Ba}$. It is the principal mineral source of Sr. Celestine mineral is present in both the propylitic and advanced argillic facies zones. The XRD analysis confirmed the identification of celestine mineral, (Fig. 50). Microscopically, the identified celestine mineral is massive pale brown anhedral to subhedral crystals, (Fig. 51). ESEM and semi-quantitative EDAX analyses, (Fig. 52 and Table 2), indicate that it has $44.44 \% \mathrm{SrO}$ and $48.40 \% \mathrm{SO}_{3}$.

Hematite $\left(\mathrm{Fe}_{2} \mathrm{O}_{3}\right)$ is the most abundant and pervasive iron oxide. It occurs as euhedral crystals of dull red colour. It is found in the studied propylitic and advanced argillic facies zones. ESEM and semi-quantitative EDAX analyses of the investigated hematite, (Fig. 53 and Table 2), show that it has minute amounts 


\section{ANAS M. EL-SHERIF}

of $\mathrm{ZnO}$ and $\mathrm{PbO}_{2}$. The XRD analysis shows that the studied hematite is associated to anhydrite and quartz, (Fig. 45).

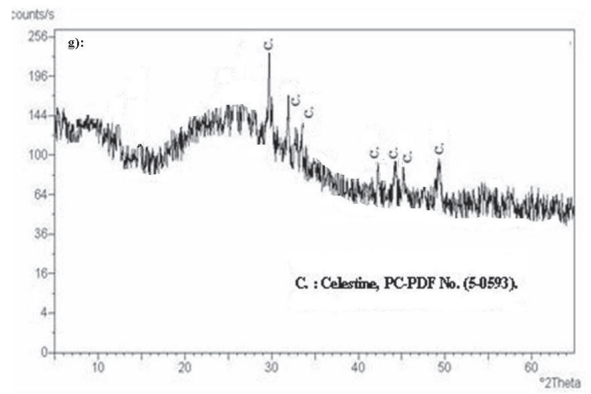

Fig.50: X-ray diffractogram of Celestine

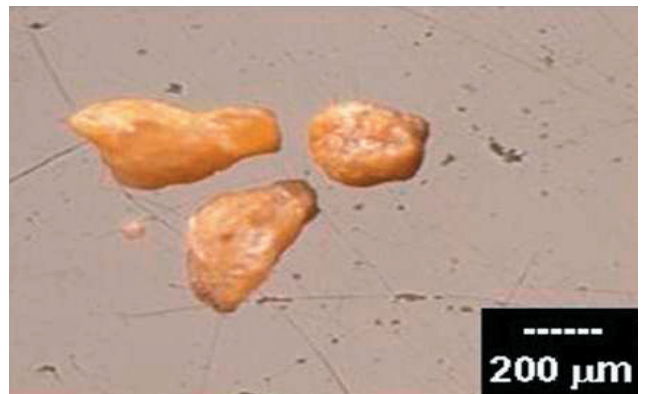

Fig.51: Pale brown celestine grains

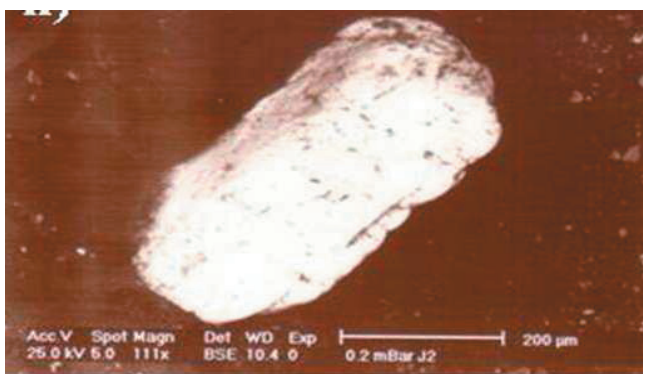

Fig.52:Celestine particle in propylitic facies zone

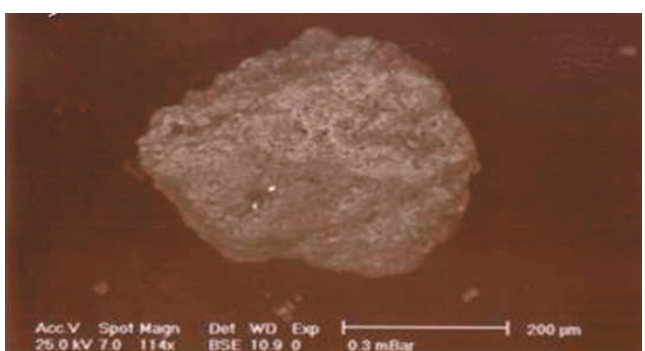

Fig.53:Hematite particle in advanced argillic facies zone
Goethite $(\mathrm{FeO} . \mathrm{OH})$ is a very common mineral occurring typically as a weathering product of iron-bearing minerals. It is normally formed under oxidizing conditions and includes much materials classed as limonite (Deer et al., 1966). In the studied two alteration facies zones, goethite represents the final stage of the alteration of the pre-existing iron minerals as magnetite and pyrite due to oxidation and hydration processes. Goethite occurs as yellowish brown to red massive grains, (Fig. 54). ESEM and semi-quantitative EDAX analyses of the study goethite, (Fig. 55 and Table 2), show that it has $\mathrm{SiO}_{2}$ up to $8.02 \%$ forming admixture and impurity in the mineral, (Deer et al., 1966).

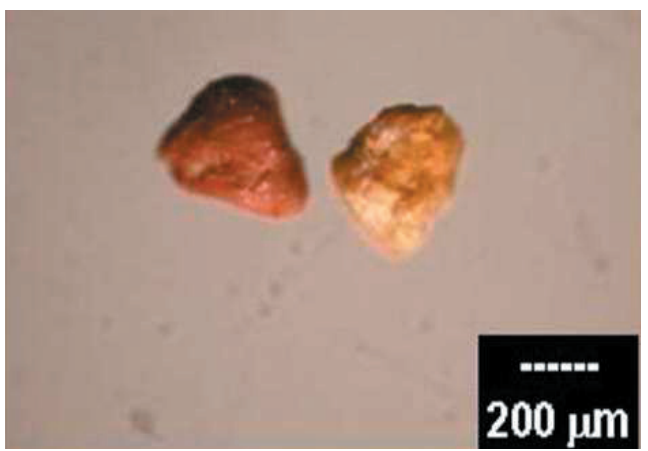

Fig.54:Yellowish brown goethite grains

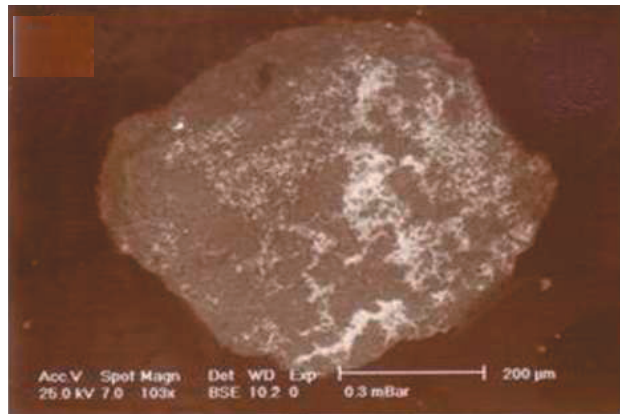

Fig.55:Goethite particle in propylitic facies zone

Fluorite $\left(\mathrm{CaF}_{2}\right)$ has a widespread occurrence as a common mineral in hydrothermal ore deposits. It displays a considerable colour variation in colour from violet, deep green to black colour (Figs. 56,57\&58). Fluorite occurs as fragments with irregular outlines and sharp 
edges. Raslan (2009) recorded a highly radioactive fluorite in the jasperoid veins in the highly sheared granite of El-Missikat pluton. ESEM and semi-quantitative EDAX analyses, (Figs. 59\&60 and Table 2), show that the deep green fluorite in the propylitic facies zone contains $\mathrm{Yb}_{2} \mathrm{O}_{3}$ and $\mathrm{Y}_{2} \mathrm{O}_{3}$ content. Actually, the studied fluorite varieties have not contain any $\mathrm{U}$ content that may be due to the EDAX lower limit of detection. The separated deep green fluorite particles contain barite mineral, (Table 2).

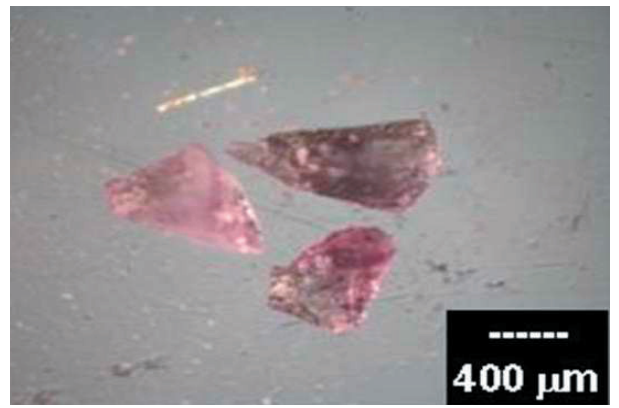

Fig.56: Violet fluorite grains

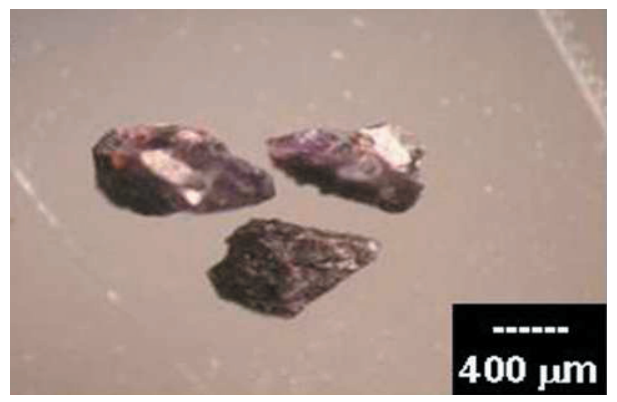

Fig.57: Deep green fluorite grains

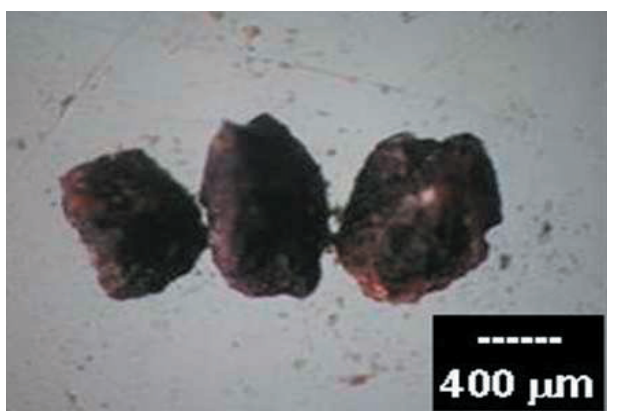

Fig.58: Black fluorite grains

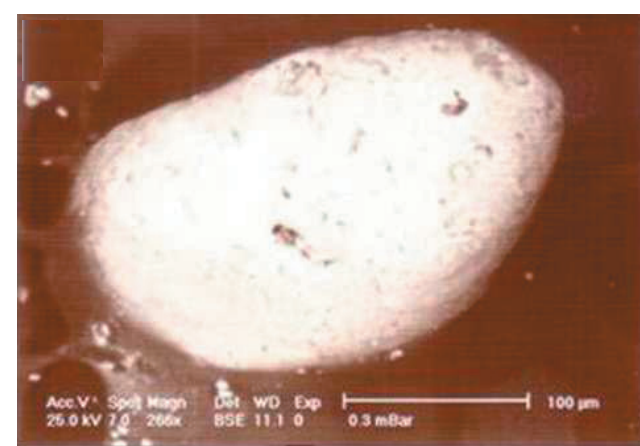

Fig.59:Deep green fluorite particle with barite inclusion in propylitic facies zone

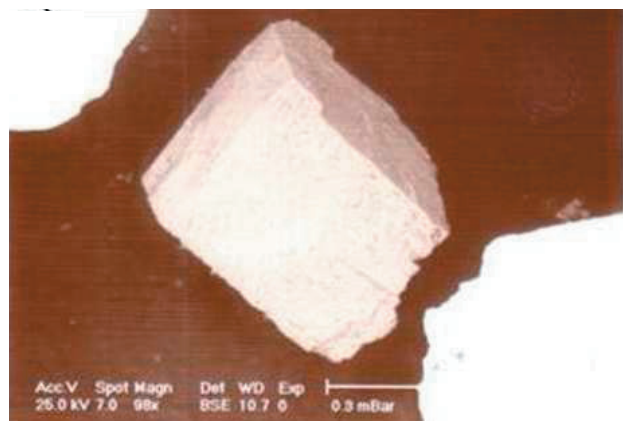

Fig.60: Violet fluorite particle in propylitic facies zone

\section{GEOCHEMICAL CHARACTERISTICS}

Meyer and Hemely (1967) classified the alteration facies into six major types; propylitic, advanced argillic, potassic, carbonate, skarn and greisen facies, each of them has its own mineralogic assemblage. The propylitic facies is characterized by the presence of quartzsericite-chlorite-epidote mineral assemblage while the presence of quartz plus one or more of the minerals: kaolinite, pyrophyllite, pyrite, alunite, zunyite and topaz characterize the advanced argillic facies. The presence of potash feldspars and/or biotite plus one or more of the minerals: sericite, chlorite and quartz characterize the potassic facies whereas calcite, dolomite, ankerite, siderite plus sericite, pyrite and/or albite mineral assemblage characterize the carbonate facies. The skarn facies is characterized by the presence of $\mathrm{Ca}$ and $\mathrm{Mg}$ silicate depend on whether the primary rock is dolomitic or calcitic, whereas the presence 
of coarse-grained muscovite, feldspars, quartz and topaz with or without tourmaline characterizes the greisen alteration facies.

The mobility of the individual major oxides and trace elements (enrichment and depletion) during alteration processes is examined by comparing their average concentrations in each facies zone of the altered granites with those in the unaltered rocks, (Fig.61). Table (3) lists the major oxides and trace elements of the analyzed alteration facies zones beside the wall rock analysis of Ibrahim et al., (2004). The main geochemical characteristic features of the studied two alteration facies are done.

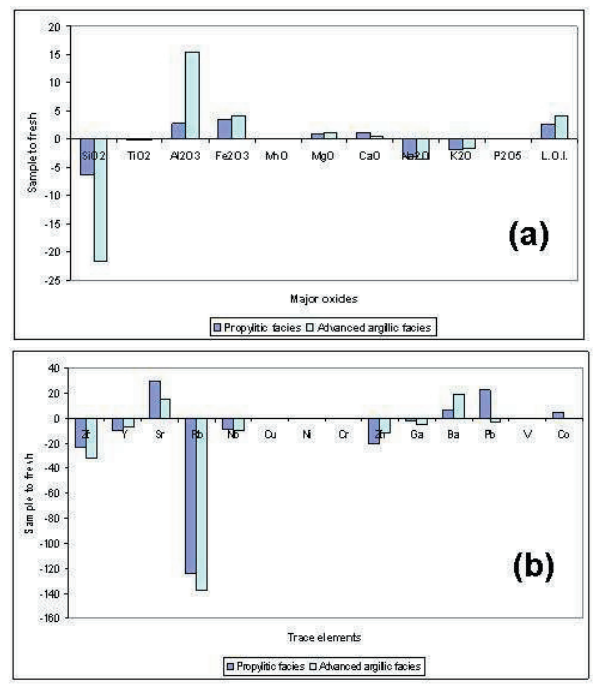

Fig.61:Enrichment-depletion diagrams of the studied alteration facies zones (a) Major oxides. (b) Trace elements.

The propylitic facies is characterized by the formation of sericite and chlorite. The amount of sericite is dependent on the initial amount of Al present, whereas the amount of chlorite depends on the availability of $\mathrm{Fe}$ and $\mathrm{Mg}$. In general, the propylitic facies zone rocks show enrichment in $\mathrm{Al}_{2} \mathrm{O}_{3}, \mathrm{Fe}_{2} \mathrm{O}_{3}, \mathrm{MgO}$, $\mathrm{CaO}, \mathrm{Sr}, \mathrm{Ba}, \mathrm{Pb}$ and $\mathrm{Co}$ and depletion in $\mathrm{SiO}_{2}$, $\mathrm{Na}_{2} \mathrm{O}, \mathrm{K}_{2} \mathrm{O}, \mathrm{Zr}, \mathrm{Y}, \mathrm{Rb}, \mathrm{Nb}, \mathrm{Zn}$ and $\mathrm{Ga}$ as compared with the unaltered rock, (Figs. $61 \mathrm{a \& b}$ ). The depletion in $\mathrm{Zr}$ and $\mathrm{Nb}$ are attributed that they have been hold in zircon and columbite respectively. Rubidium is depleted due to its big similarity with K. Gallium is known to substitute for Al. The enrichment in $\mathrm{Sr}$ is attributed to its similarity with $\mathrm{Ca}$.

Table 3 : Average chemical analyses, (major oxides and some trace elements) of the studied alteration facies zones as well as the wall rock

\begin{tabular}{|c|c|c|c|}
\hline $\begin{array}{l}\text { Facies } \\
\text { zone }\end{array}$ & Propylitic & $\begin{array}{r}\text { Advanced } \\
\text { Argillic }\end{array}$ & $\underset{\text { Rock }^{*}}{\text { Wall }}$ \\
\hline \multicolumn{4}{|c|}{ Major oxides (wt\%) } \\
\hline $\mathrm{SiO}_{2}$ & 70.0 & 54.5 & 76.3 \\
\hline $\mathrm{TiO}_{2}$ & 0.01 & 0.01 & 0.07 \\
\hline $\mathbf{A l}_{2} \mathbf{O}_{3}$ & 15.3 & 28.1 & 12.6 \\
\hline $\mathrm{Fe}_{2} \mathrm{O}_{3}$ & 4.5 & 5.1 & 0.98 \\
\hline MnO & 0.01 & 0.03 & --- \\
\hline МgO & 0.8 & 1.2 & 0.01 \\
\hline $\mathrm{CaO}$ & 2.0 & 1.2 & 0.75 \\
\hline $\mathrm{Na}_{2} \mathrm{O}$ & 0.9 & 0.5 & 4.11 \\
\hline $\mathbf{K}_{2} \mathbf{O}$ & 2.6 & 2.8 & 4.47 \\
\hline $\mathbf{P}_{2} \mathbf{O}_{5}$ & 0.01 & 0.03 & 0.03 \\
\hline L.O.I. & 2.7 & 4.3 & 0.07 \\
\hline Total & 98.9 & 97.77 & 99.39 \\
\hline \multicolumn{4}{|c|}{ Trace elements (ppm) } \\
\hline $\mathbf{Z r}$ & 99 & 90 & 122 \\
\hline $\mathbf{Y}$ & 78 & 81 & 87.9 \\
\hline Sr & 46 & 32 & 16.8 \\
\hline $\mathbf{R b}$ & 127 & 113 & 251 \\
\hline Nb & 32 & 31 & 41.1 \\
\hline $\mathbf{C u}$ & 13 & 16 & --- \\
\hline $\mathbf{N i}$ & 6 & 4 & --- \\
\hline $\mathbf{C r}$ & 9 & 12 & --- \\
\hline $\mathbf{Z n}$ & 29 & 38 & 50.1 \\
\hline Ga & 25 & 22 & 27.4 \\
\hline Ba & 88 & 101 & 81.6 \\
\hline $\mathbf{P b}$ & 40 & 14 & 17.8 \\
\hline $\mathbf{V}$ & 16 & 6 & --- \\
\hline Co & 9 & 4 & 4.2 \\
\hline
\end{tabular}

The advanced argillic facies is characterized by the formation of kaolinite. It shows enrichment in $\mathrm{Al}_{2} \mathrm{O}_{3}, \mathrm{Fe}_{2} \mathrm{O}_{3}, \mathrm{MgO}, \mathrm{CaO}, \mathrm{Sr}$ and $\mathrm{Ba}$ as compared with the wall rock, whereas $\mathrm{SiO}_{2}, \mathrm{Na}_{2} \mathrm{O}, \mathrm{K}_{2} \mathrm{O}, \mathrm{Zr}, \mathrm{Y}, \mathrm{Rb}, \mathrm{Nb}, \mathrm{Zn}, \mathrm{Ga}$ and $\mathrm{Pb}$ are depleted, (Figs. $61 \mathrm{a} \& \mathrm{~b}$ ).

The association of illite and kaolinite has been identified by XRD analysis, (Fig.18). Also, the enrichment of Fe and Mg may explain the presence of chlorite in this facies zone. The enrichment of Al may be attributed to the advanced argillic facies zone. Strontium and $\mathrm{Ba}$ are relatively enriched in advanced argillic facies zone owing to their incorporation of own celestine and barite minerals respectively. 


\section{RADIOACTIVITY}

Radioactivity of El-Missikat area has been discussed by many authors. A total of six samples representing the two alteration facies zones of El-Missikat granitic pluton were analyzed for equivalent uranium and equivalent thorium contents. Table (4) shows eU and eTh content as well as eTh/eU ratios of the study alteration facies zones.

Table 4 : eU and eTh (ppm) as well as $\mathrm{Th} / \mathrm{U}$ ratio of the studied alteration facies zones

\begin{tabular}{lrrrr}
\hline Alteration & Sp. No. & eU & eTh & eTh/eU \\
\hline \multirow{3}{*}{ Propylitic facies zone } & 1 & 2972 & 128 & 0.04 \\
& 2 & 5 & 38 & 7.6 \\
& 3 & 13 & 26 & 2 \\
\hline \multirow{3}{*}{ Advanced argillic facies zone } & 4 & 2641 & 166 & 0.06 \\
& 5 & 21 & 23 & 1.10 \\
& 6 & 7 & 49 & 7.00 \\
\hline
\end{tabular}

From the above table, we can divide the study alteration rocks of El-Missikat area into two types; the first one of the mineralized rocks and the second of non-mineralized rocks. The propylitic facies zone has eU content ranging from 5 to $2972 \mathrm{ppm}$ and $\mathrm{eTh}$ content ranging from 26 to $128 \mathrm{ppm}$ with $\mathrm{eTh} / \mathrm{eU}$ ratio ranging from 0.04 to 7.6 . The advanced argillic facies zone has eU content ranging from 7 to 2641 ppm and eTh content ranging from 23 to 166 ppm with eTh/eU ratio ranging from 0.06 to 7 . The high eU content in samples 1 and 4 is attributed to the presence of the uranium minerals uranophane and kasolite or uranium bearing columbite, zircon, fluorite and rutile.

\section{DISCUSSION AND CONCLUSIONS}

The relationships between fluids, rocks and alteration mineral assemblages can be used to systematize the examination of alteration processes in terms of rock types, fluid types and temperature. Also, Ramdohr (1980) classified the hydrothermal deposit occurrences into veins, replacements and impregnations according to the chemical behavior of the country rocks, according to presence or absence of cracks and pores as well as the nature of the ore-forming solutions.
Two alteration facies zones were recognized in Gabal El-Missikat area, namely propylitic and advanced argillic zones which reflect the presence of various hydrothermal deposit occurrences (veins, replacement and impregnation types). The alteration processes expressed by: 1) dissolution of K-feldspars and Fe-phyllosilicates and illite precipitation associated with development of microcracks, 2) partial dissolution of plagioclase with partial chloritization of biotites, and 3 ) biotite dissolution and precipitation of Fe-phyllosilicates in the dissolution pores.

The hydrothermal alteration processes are accompanied mainly by a dissolution-precipitation process resulting from the infiltration of hydrothermal fluids along microcracks that can be explained by the reactions of Arnorsson et al., (1982) through three stages:

\section{The First Stage}

The hydrolysis of potash feldspars leads to formation of illite (propylitic facies) according to the following reaction:

$$
\underset{\text { K-feldspar }}{3 \mathrm{KAlSi}_{3} \mathrm{O}_{8}}+2 \mathrm{H}^{+} \longrightarrow \underset{\text { K-mica (Illite) }}{\mathrm{KAl}_{3} \mathrm{Si}_{3} \mathrm{O}_{10}(\mathrm{OH})_{2}}+\underset{\text { Quartz }}{6 \mathrm{SiO}_{2}}+2 \mathrm{~K}^{+}
$$

The hydration of illite leads to formation of kaolinite and then the formation of the advanced argillic facies according to the following reaction:

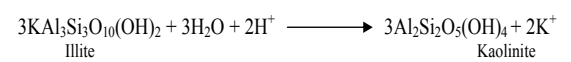

The released silica reacts with the anorthite to form zoisite and secondary albite as the following reaction:

$2 \mathrm{CaAl}_{2} \mathrm{Si}_{2} \mathrm{O}_{8}+4 \mathrm{SiO}_{2}+2(\mathrm{OH})^{+}+2 \mathrm{Na}^{+} \longrightarrow \mathrm{Ca}_{2} \mathrm{Al}_{3} \mathrm{Si}_{3} \mathrm{O}_{12}\left(\mathrm{OH}_{2}+2 \mathrm{NaAlSi}_{3} \mathrm{O}_{8}+2 \mathrm{H}^{+}\right.$

The hydration of albite leads to the formation of kaolinite and more quartz as well as the liberation of sodium as the following reaction:

$2 \mathrm{NaAlSi}_{3} \mathrm{O}_{8}+3 \mathrm{H}_{2} \mathrm{O} \longrightarrow \mathrm{Al}_{2} \mathrm{Si}_{2} \mathrm{O}_{5}(\mathrm{OH})_{4}+2 \mathrm{Na}^{+}+2(\mathrm{OH})^{-}+4 \mathrm{SiO}_{2}$

The propylitic facies zone is mainly related to strongly alkaline hydrothermal solutions at $\mathrm{pH}$ value of more than 7 with temperature varying between 350 and $450^{\circ} \mathrm{C}$ (Sweewald 
and Sayfried, 1990). On the other hand, the advanced argillic facies zone is essentially associated with strongly acidic hydrothermal solutions at $\mathrm{pH}$ value less than 7 with temperature varying between 150 and $400^{\circ} \mathrm{C}$, (Bucanan, 1982). Also, Abdel Monem et al., (2001) concluded that the mineral assemblage (chlorite-epidote-carbonates-fluorite) in the propylitic facies were formed by hydrolysis reactions involving dissolved $\mathrm{Fe}^{++}$and zoisite to form epidote which reacts with more dissolved $\mathrm{Fe}^{++}$ in presence of $\mathrm{CO}_{2}$ to form Fe-chlorite and calcite. They also concluded that the mineral assemblage (sericite-chlorite-carbonates-epidote) in the argillic facies were formed by hydrolysis reactions involving dissociated water, dissolved silica and feldspar leading to the formation of K-mica and kaolinite, the released $\mathrm{Na}^{+}$and $\mathrm{SiO}_{2}$ react with anorthite to form zoisite and albite.

\section{The Second Stage}

The presence of quartz veins in the studied facies result from the released silica of reaction (1) and (4). On the other hand, the presence of magnetite, pyrite, hematite and goethite minerals in the studied alteration facies reflects the following hydration mechanisms:

The hydrolysis of magnetite leads to the formation of $3 \mathrm{Fe}(\mathrm{OH})_{3}^{-}$and hydrogen ions according to the following reaction:

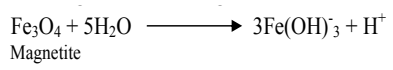

The hydration of hematite leads to the formation of goethite as the following reaction:

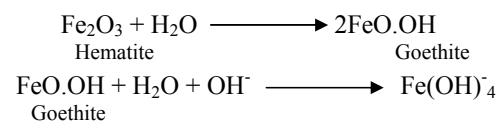

The hydration of pyrite leads to liberate $\mathrm{SO}_{4}^{---}$as the following reaction:

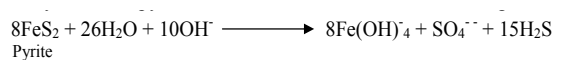

Also, the hydration of anorthite in reaction (3) releases $\mathrm{Ca}^{2+}, \mathrm{Sr}^{2+}$ and $\mathrm{Ba}^{2+}$ reacts with the liberated sulphur which leads to formation of anhydrite, celestine and barite minerals respectively.
On the other hand, the zoisite produced from the reaction (3) reacts with the iron enriched in the two alteration facies zone to form epidote as the following reaction:

$\underset{\text { Zoiste }}{\mathrm{Ca}_{2} \mathrm{Al}_{3} \mathrm{Si}_{3} \mathrm{O}_{12}(\mathrm{OH})_{2}}+\mathrm{Fe}(\mathrm{OH})_{3}+3 \mathrm{H}^{+} \longrightarrow \underset{\text { Epidote }}{\longrightarrow} \underset{\mathrm{Ca}_{2} \mathrm{Fe}^{+3} \mathrm{Al}_{2} \mathrm{Si}_{3} \mathrm{O}_{12}(\mathrm{OH})+3 \mathrm{H}_{2} \mathrm{O}}{ }$

The produced epidote reacts with the released iron to form chlorite and calcite as the following reaction:

$\mathrm{Ca}_{2} \mathrm{Fe}^{+3} \mathrm{Al}_{2} \mathrm{Si}_{3} \mathrm{O}_{22}(\mathrm{OH})+2 \mathrm{CO}_{2}+4 \mathrm{Fe}\left(\mathrm{OH}_{2}+\mathrm{H}^{+} \longrightarrow \mathrm{Fe}_{5} \mathrm{Al}_{2} \mathrm{Si}_{3} \mathrm{O}_{10}\left(\mathrm{OH}_{3}+2 \mathrm{CaCO}_{3}+\mathrm{H}_{2} \mathrm{O}\right.\right.$

The calcite produced reacts with the fluoride ion that produced from the dissolution of biotite to form fluorite veins that present in the propylitic and advanced argillic facies zones.

The presence of fluorite may give good evidence indicating that the studied alteration facies zones are mainly due to the hydrothermal solutions. Bucanan (1982) denoted that the presence of fluorite may reflect acidic solutions saturated with silica of temperature ranging between 200 and $300^{\circ} \mathrm{C}$.

\section{The Third Stage}

The presence of secondary uranium minerals (uranophane and kasolite) at El-Missikat area may reflect a thermal water alteration process. Abdel Nabi (2009) explains the formation of uranophane mineral as a two stages mechanism. The first one is usually dominated by hydrothermal alteration and accompanied by albitization, K-feldspathization, desilicification, chloritization, hematitization, silicification, argillization, fluoritization and corrosion of the first U-bearing minerals. The second one occurred near the surface where circulating thermal water played an important role in mobilizing the early formed first U-bearing minerals. After that the uranium was transported as a calcium uranyl carbonate complexes. When these complexes lost their stabilities by precipitation of calcite, they decomposed in the presence of silica to form uranophane.

\section{Acknowledgements}

I am indebted to Emeritus Prof. Abdalla A. Abdel Monem of NMA for his continuous 
valuable discussions during the critical reading of numerous manuscripts, to Late Prof. Fathy A. Ammar of NMA for his help offered in minerals identification, to Late Prof. Ewais M. Moussa of NMA for endless assistance during all stages of this text and also to Prof. Sayed A. Omar of NMA for supporting the sampling.

\section{REFERENCES}

Abdallah, S.M., 1998. Subsurface geologic studies of El-Missikat uranium occurrence, Central Eastern Desert, Egypt. M.Sc. Thesis, Fac. Sci., Cairo Univ., Egypt, 152p.

Abdel Monem, A.A.; Shazly, A.G.; Salem, I.A. and El-Shibiny, N.H.M., 2001. Mineralogy and geochemistry of hydrothermally altered granites associated with rare metals mineralizations, Central Eastern Desert, Egypt. 5th Inter. Conf. Geochem., Fac. Sci., Alexandria Univ., Egypt, 405-422.

Abdel Nabi, H.H., 2009. High and low temperature alteration of uranium and thorium minerals, Um Ara granites, South Eastern Desert, Egypt. Ore Geol. Rev., 35 (3-4), 436-446.

Abu-Deif, A.A., 1985. Geology of uranium mineralization in El-Missikat area, Qena-Safaga road, Eastern Desert, Egypt. M.Sc. Thesis, Fac. Sci., Al-Azhar Univ., Egypt, 103p.

Abu-Deif, A.A., 1992. The relation between the uranium mineralization and tectonics in some Pan-African granites, west of Safaga, Eastern Desert, Egypt. Ph.D. Thesis, Fac. Sci., Assiut Univ., Egypt, 218p.

Abu-Deif, A.A. and El-Taher, M., 2008. A new uranium occurrence, Gabal El-Missikat prospect, Central Eastern Desert, Egypt. J. King Abdul Aziz Univ., Earth Sci., 19, 85-97.

Abu-Deif, A.A.; Saleh, E.A. and Mohamed, N.A., 1997. Geological and geochemical studies of black silica at El-Missikat pluton, Central Eastern Desert. Egypt. Proc. Egy. Acad. Sci., 47, 335-346.
Abu-Deif, A.A.; El-Husseiny, M.O.; El-Balakssy, S.S. and Abu-Zeid, E.K., 2007. Wall rock alteration and uranium mineralization at M-III uranium occurrence, Gabal El-Missikat younger granites, Central Eastern Desert, Egypt. 2nd Inter. Conf. Geol. Tethys, Fac. Sci., Cairo Univ., Egypt, 647-654.

Ahmed, N.A., 1991. Comparative study of the accessory heavy minerals in some radioactive rocks of Gabal Erediya, Eastern Desert and their alluvial deposits. M.Sc. Thesis, Fac. Sci., Cairo Univ., Egypt, 137p.

Amer, T.E.; Ibrahim, T.M. and Omar, S.A., 2005. Microprobe studies and some rare metals recovery from El-Missikat mineralized shear zone, Eastern Desert, Egypt. 4th Inter. Conf. Geol. Africa, Fac. Sci., Assiut Univ., Egypt, 2, 225-238.

Ammar, A.A., 1973. Application of aerial radiometry to the study of the geology of Wadi El-Gidami area, Eastern Desert, Egypt, (with aeromagnetic applications). Ph.D. Thesis, Fac. Sci., Cairo Univ., Egypt, 424p.

Ammar, F.A., 2007. Mineralogical and geochemical studies for the sulphide minerals association in Gabal El-Missikat uranium mineralization, Central Eastern Desert, Egypt. Egy. Mineral., (In Press).

Arnorsson, S.; Sigurdsson, S. and Svarvarsson, H., 1982. The chemistry of geothermal waters in Iceland. I. Calculation of aqueous speciation from $0^{\circ}$ to $370^{\circ} \mathrm{C}$. Geochim. Cosmochim., Acta, $46,1513-1532$.

Attawiya, M.Y., 1983. Geochemistry and genesis of the uranium mineralization of Gebel El-Misikat, Egypt. Ann. Geol. Surv. Egy., XIII, 67-74.

Bakhit, F.S., 1978. Geology and radioactive mineralization of Gabal El-Missikat area, Eastern Desert, Egypt. Ph.D. Thesis, Fac. Sci., Ain Shams Univ., Egypt, 289p.

Bakhit, F.S. and Mostafa, M.E., 1987. Structural analysis of the main uraniferous chalcedony vein at Gabal El-Missikat environs, Central 


\section{ANAS M. EL-SHERIF}

Eastern Desert, Egypt. Inter. J. Remot. Sens., 8(5), 765-777.

Bakhit, F.S. and El-Kassas, I.A., 1989. Distribution and orientation of radioactive veins in the El-Erediya-El-Missikat area, Central Eastern Desert, Egypt. Inter. J. Remot. Sens., 10(3), 565-581.

Bakhit, F.S.; Assaf, H.A. and Abu-Deif, A.A., 1985. Correlation study on the geology and radioactivity of surface and subsurface working in ElMissikat area, Central Eastern Desert, Egypt. Mining. Geol., 35, 345-354.

Bucanan, M.S., 1982. The geochemistry of some igneous rock series. Geochim. Cosmochim., Acta, 9, 101-137.

Deer, W.A.; Howie, R.A. and Zussman, J., 1966. An Introduction To The Rock Forming Minerals. Longman, London, 528p.

El-Kassas, I.A., 1974. Radioactivity and geology of Wadi Atalla area, Eastern Desert of Egypt. Ph.D. Thesis, Fac. Sci., Ain Shams Univ., Egypt, 502p.

El-Shazly, E.M.; Dixon, T.H.; Engel, A.E.J.; Abdel Meguid, A.A. and Stern, R.J., 1981. Late-Precambrian crustal evolution of Afro-Arabia from Oceanic Arc to Craton. Egy. J. Geol., 4 (1-2), 101-121.

El-Tahir, M.A., 1985 Radioactivity and mineralization of granitic rocks of El-Missikat occurrence, Eastern Desert, Egypt. Ph.D. Thesis, Fac. Sci., Al-Azhar Univ., Egypt, 132p.

Habib, M.E., 1982. Landsat investigation of mineralized granites in the area between Gabals El-Urf and El-Erediya due to west of Safaga, Egypt. 8th Inter. Symp. Machine Processing of Remotely Sensed Data, LARS/Purdue Univ., west Lafayette, U.S.A., 441-446.

Heinrich, E.W., 1962. Radioactive columbite. Amer. Mineral., 47, 1363-1379.

Hussein, H.A.; Hassan, M.A.; El-Tahir, M.A. and Abu-Deif, A.A., 1986. Uranium bearing siliceous veins in younger granites, Eastern Des- ert, Egypt. Inter. Atom. Ener. Agen. (IAEA), TECDOC 361, 143-157.

Ibrahim, T.M., 2002. Geologic and radioactive studies of the basement-sedimentary contact in the area west Gabal El-Missikat, Eastern Desert, Egypt. Ph.D. Thesis, Fac. Sci., Mansoura Univ., Egypt, 214p.

Ibrahim, T.M.; Cuney, M.; El-Agami, N.L.; Abdel Meguid, A.A. and Zalata, A.A., 2004. Alteration processes and elements mobility in El-Missikat granite, Eastern Desert, Egypt. 6th Inter. Conf. Geoch., Fac. Sci., Alexandria Univ., Egypt, 465-481.

Matolin, M., 1990. Construction and use of spectrometric calibration pads, Laboratory gammaray spectrometry. A report to the government of the Arab Republic of Egypt, Framework of The IAEA Project, EGY / 4 / 030-03.

Meyer, C. and Hemely, J.J., 1967. Wall rock alteration. In: Geochemistry of Hydrothermal Ore Deposits (Barnes, H.L.,ed.). Holt, Rinehart and Winston, New York, 166-235.

Mohamed, N.A., 1988. Mineralogical and petrographical characteristics of some alteration products related to U-mineralization in El-Missikat, El-Erediya area. Eastern Desert, Egypt. M.Sc. Thesis, Fac. Sci., Cairo Univ., Egypt, $118 \mathrm{p}$.

Mohamed, N.A., 1995. Distribution and extraction of uranium and some trace elements from the mineralized zones of El-Missikat-El-Erediya area. Eastern Desert, Egypt. Ph D. Thesis, Fac. Sci., Cairo Univ., Egypt, 185p.

Nagy, R.M., 1977. Geochemistry of Raba El-Garra pluton, Egypt. Ph.D. Thesis, Rice Univ., U.S.A., 73p.

Orabi, F., 1999. Geologic, petrographic and geochemical studies of uraniferous granitoids in El-Garra-El-Gidami area, Central Eastern Desert, Egypt. Ph.D. Thesis, Fac. Sci., South Valley Univ. (Qena Branch), 151p.

Rabie, S.I.; Assaf, H.S.; El-Kattan, E.M. and Othman, H.S., 1996. Uranium exploration in El- 
Missikat prospect area, Central Eastern Desert, Shapiro, L. and Brannock, W.W., 1962. Rapid analEgypt. Rad. Phys. Geochem., 47 (5), 769-774.

Ramdohr, P., 1980. The Ore Minerals and Their Intergrowths. Pergamon Press, 1207p.

Raslan, M.F., 2009. Mineralogical and geochemical characteristics of uranium-rich fluorite in El-Missikat mineralized granite, Central Eastern Desert, Egypt. Geologija, 52/2, 213-220, ysis of silicate, carbonate and phosphate rocks. Bull. U.S. Geol. Surv., 1144 (A), 56p.

Sweewald, J.S. and Syfried, J.W., 1990. The effect of temperature on metal mobility in subseafloor hydrothermal systems, constrains from basalt alteration experiments. Earth Planet. Sci. Lett., $101,388-403$.

Ljubljana.

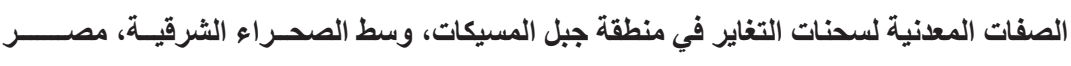

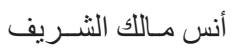

تهتم هذه الدر اسة بالصفات البتروجر افية، المعدنية و الكيميائية لنطاقات سحنات التغاير الموجودة حول نطاق القص

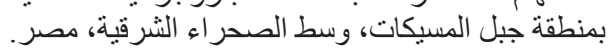

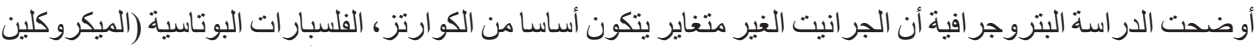

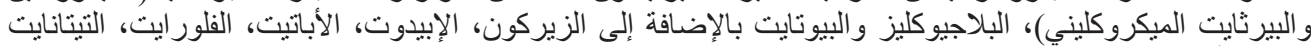
ومعادن أكاسيد الحديد المعتمة كمعادن إضيافية البانية.

تم التعرف على نطاقين لسحنات التغاير و هما نطاق سحنة التغاير البروبيليتية ونطاق سحنة التغاير الطينية المتقدمة.

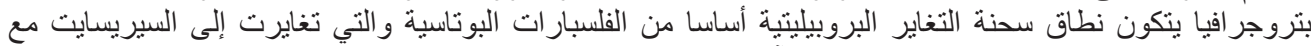

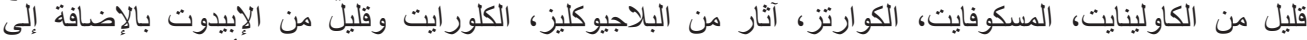

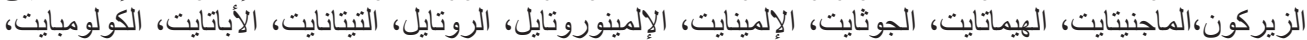

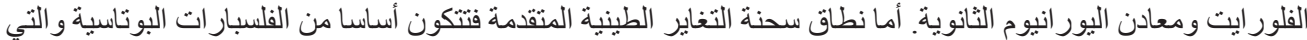

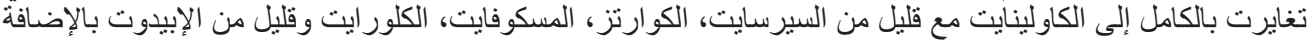

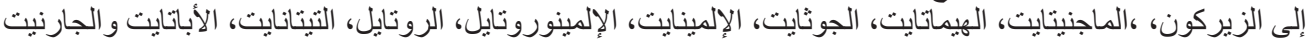

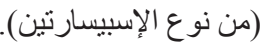

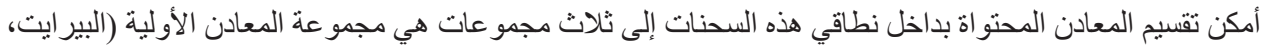

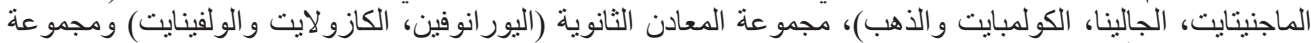
معادن الخبث (الأنهيدر ايت، البار ايت، السيليستين، الهيماتايت، الجوثايت والفيت الفلور ايت).

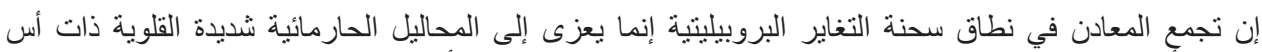

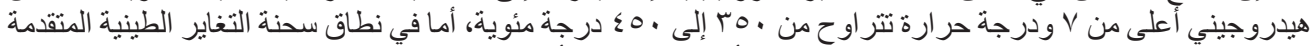

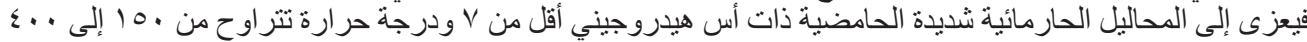
درجة مئوية. 